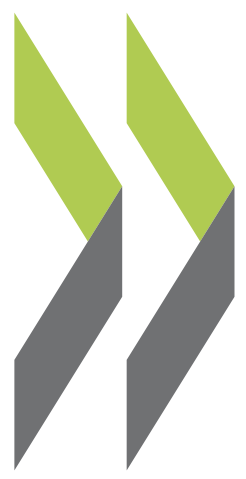

SIGMA Papers No. 24

\title{
Central Bank Audit Practices
}

\section{OECD}




\section{CENTRAL BANK AUDIT PRACTICES}

SIGMA PAPERS: No. 24 


\section{THE SIGMA PROGRAMME}

SIGMA - Support for Improvement in Governance and Management in Central and Eastern European Countries is a joint initiative of the OECD Centre for Co-operation with Non-Member Economies and the European Union's Phare Programme. The initiative supports public administration reform efforts in thirteen countries in transition, and is principally financed by Phare.

The Organisation for Economic Co-operation and Development is an intergovernmental organisation of 29 democracies with advanced market economies. The Centre channels the Organisation's advice and assistance over a wide range of economic issues to reforming countries in Central and Eastern Europe and the former Soviet Union. Phare provides grant financing to support its partner countries in Central and Eastern Europe to the stage where they are ready to assume the obligations of membership of the European Union.

Phare and SIGMA serve the same countries: Albania, Bosnia-Herzegovina, Bulgaria, the Czech Republic, Estonia, the Former Yugoslav Republic of Macedonia, Hungary, Latvia, Lithuania, Poland, Romania, Slovakia and Slovenia.

Established in 1992, SIGMA works within the OECD's Public Management Service, which provides information and expert analysis on public management to policy-makers and facilitates contact and exchange of experience amongst public sector managers. SIGMA offers beneficiary countries access to a network of experienced public administrators, comparative information, and technical knowledge connected with the Public Management Service.

SIGMA aims to:

- assist beneficiary countries in their search for good governance to improve administrative efficiency and promote adherence of public sector staff to democratic values, ethics and respect of the rule of law;

- help build up indigenous capacities at the central governmental level to face the challenges of internationalisation and of European Union integration plans; and

- support initiatives of the European Union and other donors to assist beneficiary countries in public administration reform and contribute to co-ordination of donor activities.

Throughout its work, the initiative places a high priority on facilitating co-operation among governments. This practice includes providing logistical support to the formation of networks of public administration practitioners in Central and Eastern Europe, and between these practitioners and their counterparts in other democracies.

SIGMA works in five technical areas: Public Administration Development Strategies; Policy-making, Co-ordination and Regulation; Budgeting and Resource Allocation; Public Service Management; and Administrative Oversight, Financial Control and Audit. In addition, an Information Services Unit disseminates published and on-line materials on public management topics.

\section{Copyright OECD, 1998}

Applications for permission to reproduce or translate all or part of this material should be made to: Head of Publications Service, OECD, 2 rue André-Pascal, 75775 Paris Cedex 16, France.

Views expressed in this publication do not represent official views of the Commission, OECD Member countries, or the central and eastern European countries participating in the Programme. 


\section{FOREWORD}

Central Bank Audit Practices describes common approaches, practices and trends relevant to the audit of central banks, with a view to supporting public administration reform efforts in central and eastern European countries. The study provides a basis for further discussion between decision-makers and practitioners on how the audit regime could be developed to ensure good governance of central banks.

This study originates from a discussion on today's important audit issues which was arranged by the European Court of Auditors together with the presidents of supreme audit institutions (SAIs) of central and eastern European countries and held in Luxembourg on 21-23 October 1996. Follow-up discussions between representatives of SAIs and central banks and SIGMA made it apparent that a focused comparative study could be of high value to officials with responsibilities for the design of audit strategies and policies, as well as to auditors.

From the outset it was decided that the study should focus on auditing of central bank activities and not on banking. This meant that aspects of the banking system, such as the regulatory structure of financial institutions or supervision of the financial sector, although very interesting and relevant, have been excluded from the scope of the study or are only briefly mentioned. The study is furthermore limited in that it provides an overview of four European Union Member States (Germany, Ireland, the Netherlands and Sweden). These countries do not represent the entire variation to be found in the EU. The reader is also asked to keep in mind that current practices might undergo important changes as a result of the introduction of the European Economic and Monetary Union.

The study was carried out on the basis of documents received from and interviews with key players in the auditing of central banks. These include managers of central banks, representatives of internal audit units, supreme audit institutions, ministries of finance and, where relevant, parliamentary auditors and representatives of debt management institutions.

A reference group was established with representatives of central banks, ministries of finance and supreme audit institutions in the Czech Republic, Estonia, Lithuania and Poland to help focus the work towards matters of importance and urgency, as well as to establish a network between professionals from different organisations and countries. In a meeting of the reference group on 15-16 September 1997, reference group members prepared papers for comment and gave guidance for improving a first draft of this report.

SIGMA is grateful to all those who contributed to this study by providing documentation and reviewing drafts of this text. SIGMA consultant Gerry Kopil commenced research and drafted a first version of this study. At the SIGMA Secretariat, the study was completed by Rudy Voet and Kjell Larsson with the administrative support of Miriam Blanco-Monterrubio, Nathalie Di Piazza and Sandrine Sabatier.

For further information, please contact Kjell Larsson at the address below.

This report is published on the responsibility of the Secretary-General of the OECD.

SIGMA-OECD, 2, rue André-Pascal, 75775 Paris, Cedex 16, France

Tel. (33.1) 45.24.79.00; Fax (33.1) 45.24.13.00

e-mail: sigma.contact@oecd.org; http://www.oecd.org/puma/sigmaweb 


\section{TABLE OF CONTENTS}

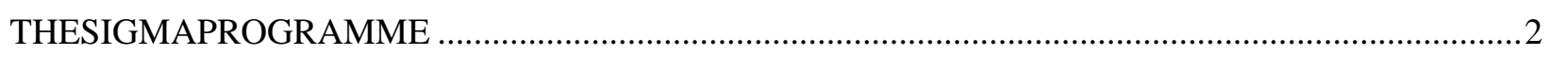

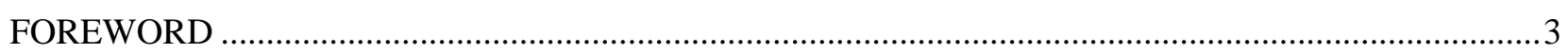

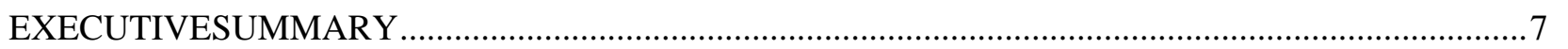

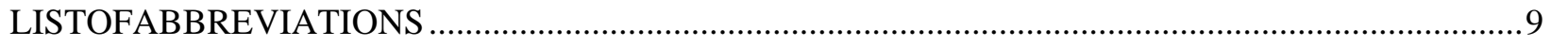

1. INTRODUCTION

2. SOME CHARACTERISTICS OF THE CENTRAL BANKS STUDIED.............................................11

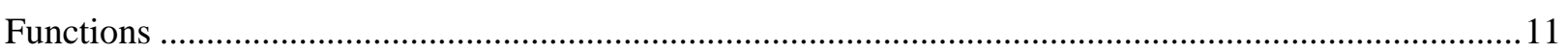

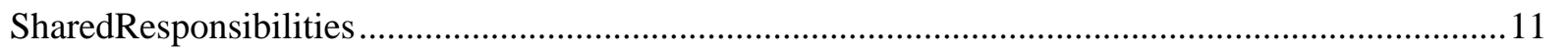

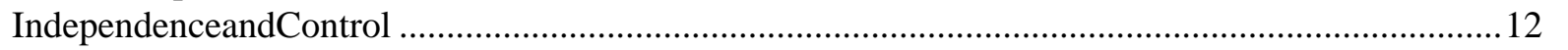

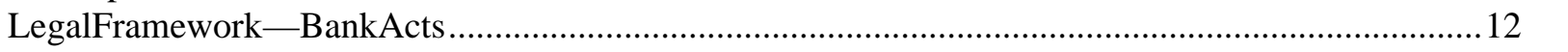

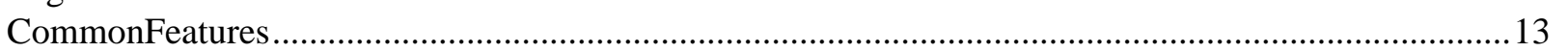

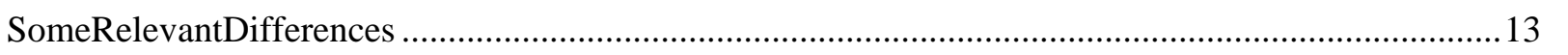

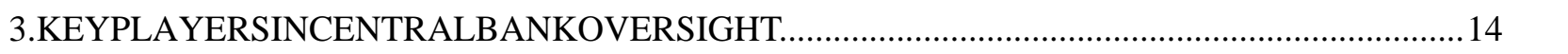

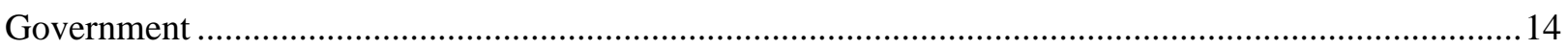

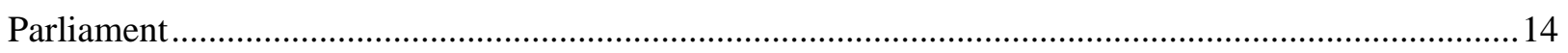

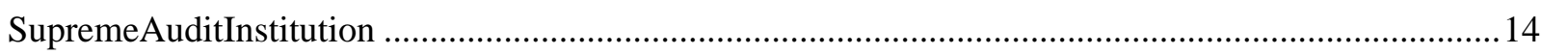

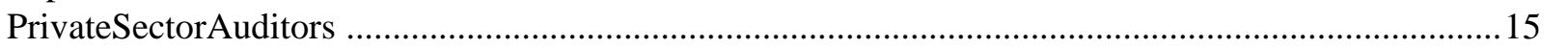

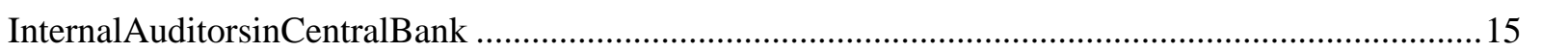

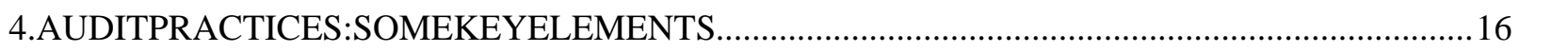

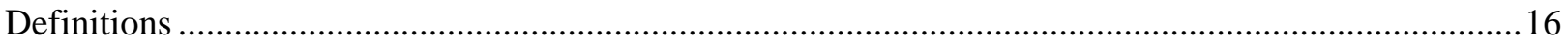

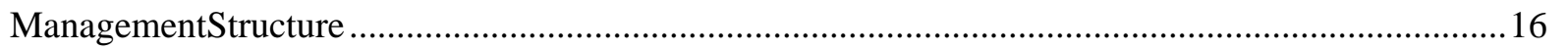

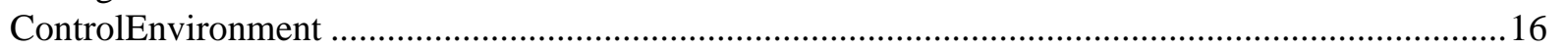

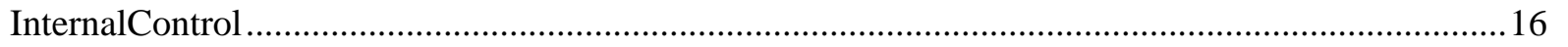

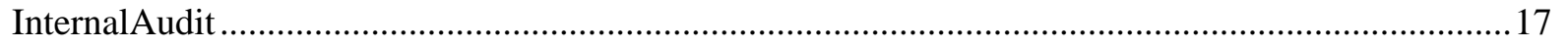

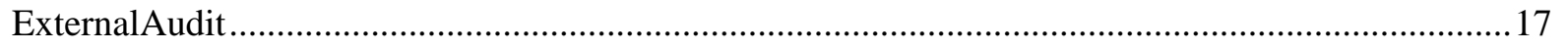

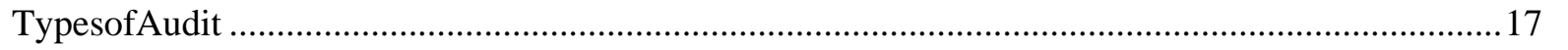

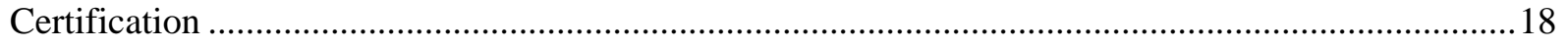

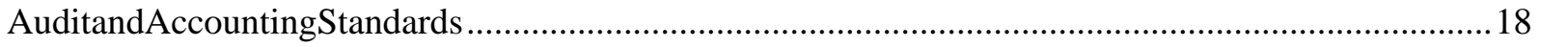

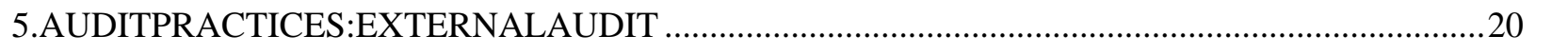

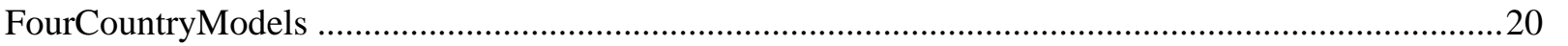

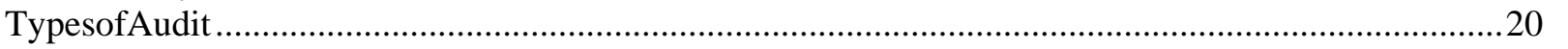

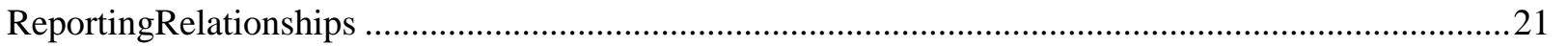




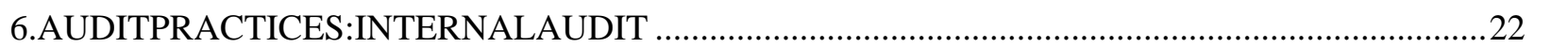

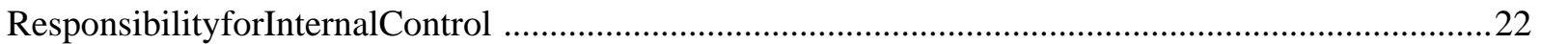

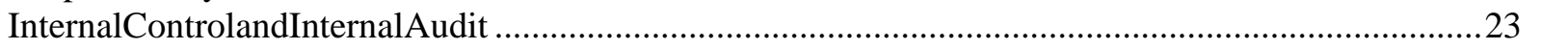

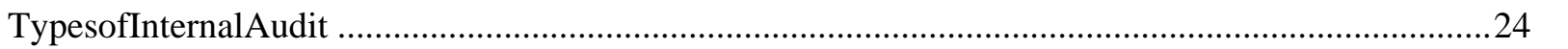

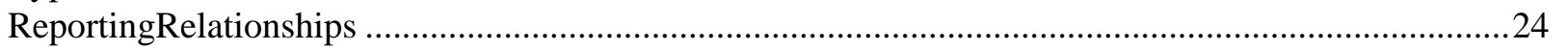

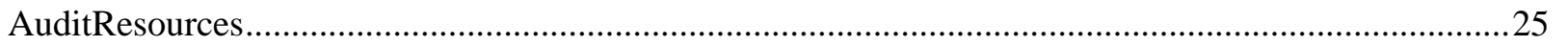

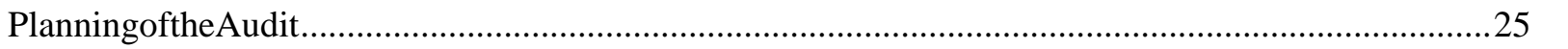

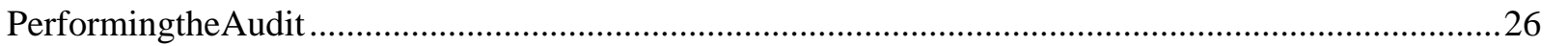

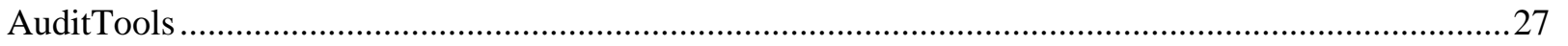

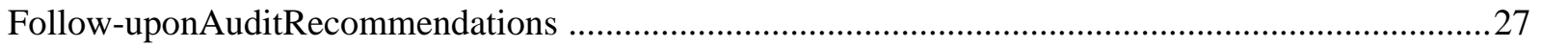

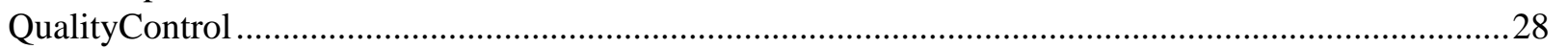

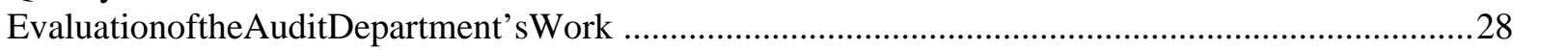

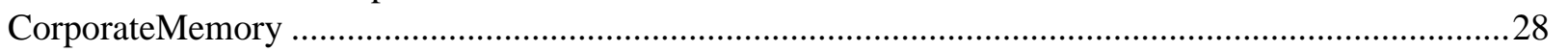

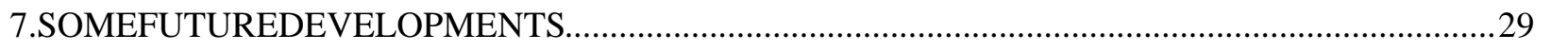

Accession to the EU — Consequences for Central Banks ....................................................................29

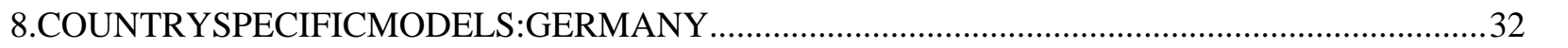

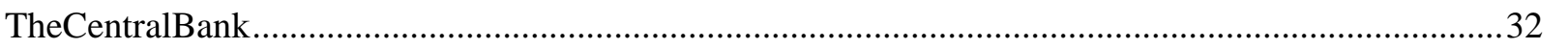

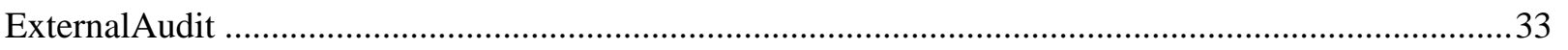

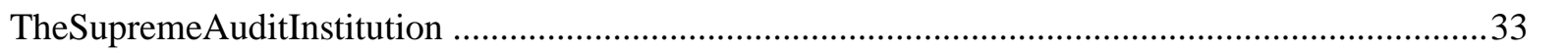

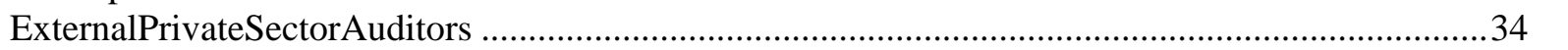

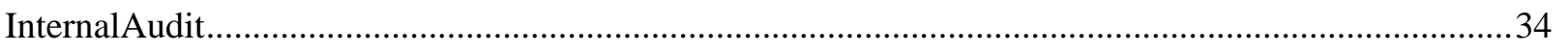

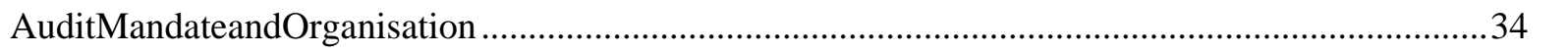

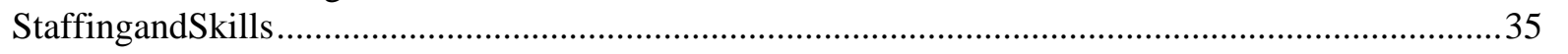

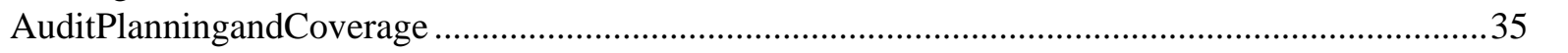

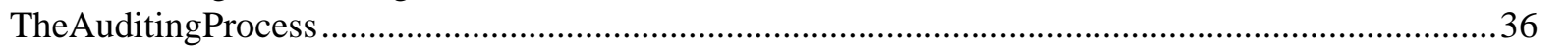

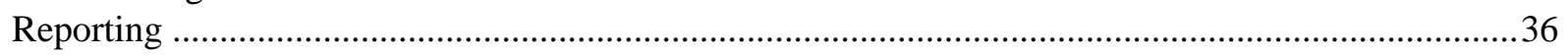

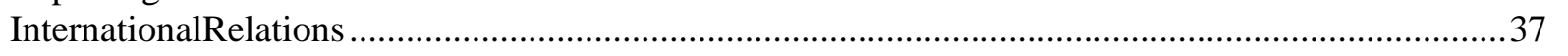

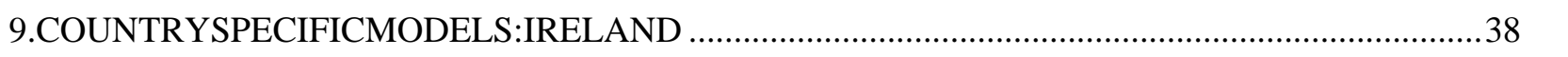

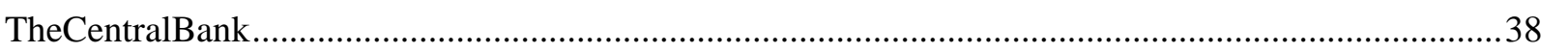

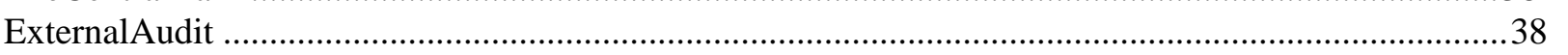

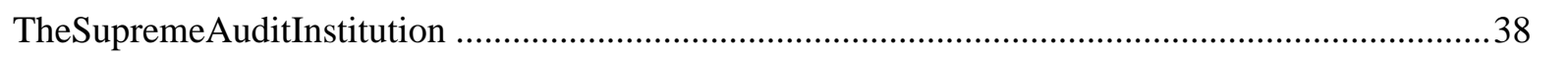

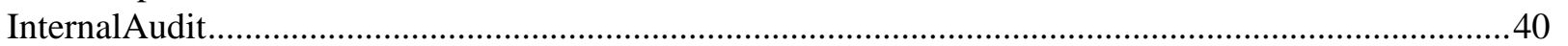

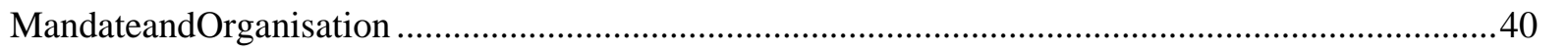

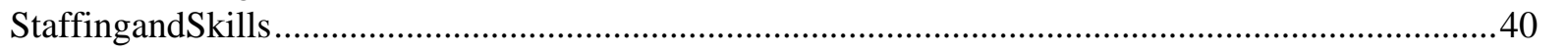

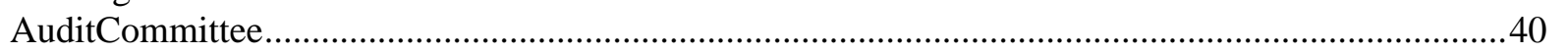

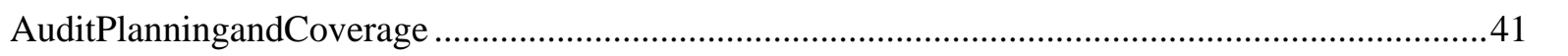

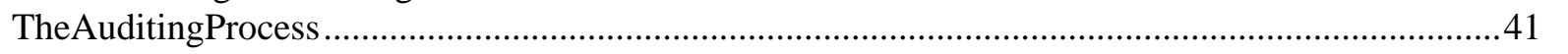

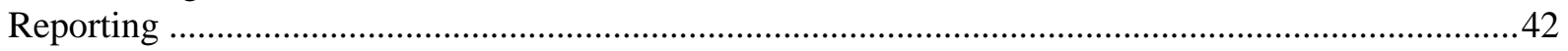

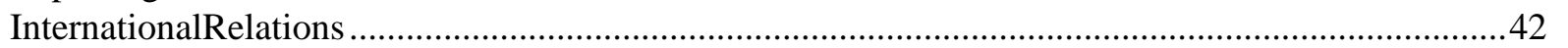




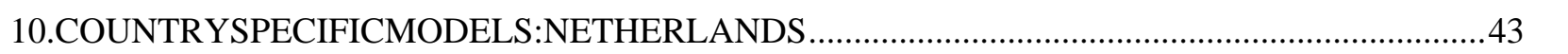

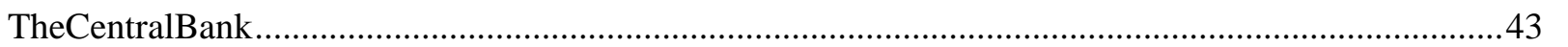

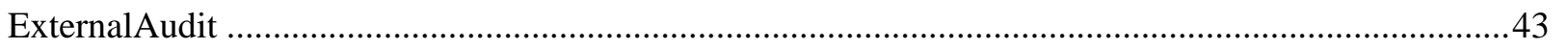

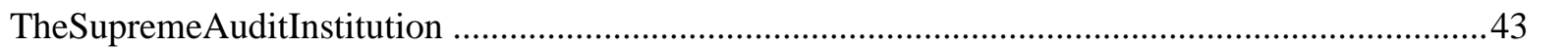

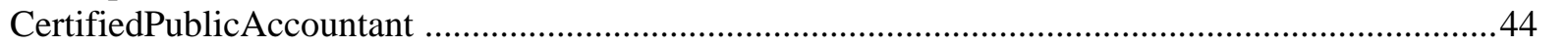

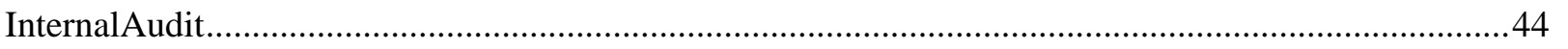

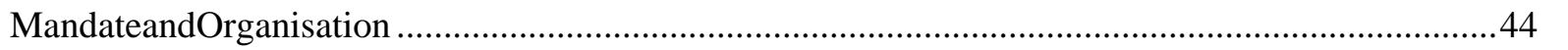

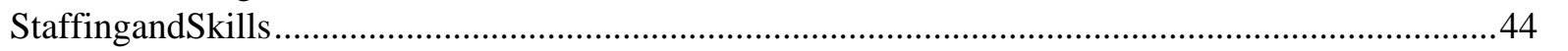

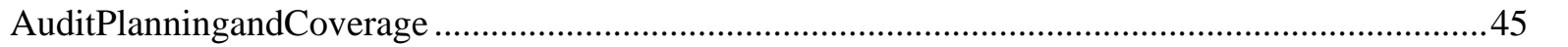

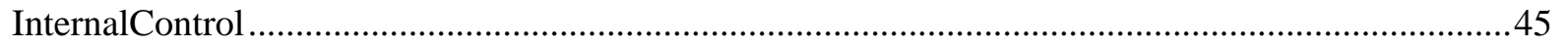

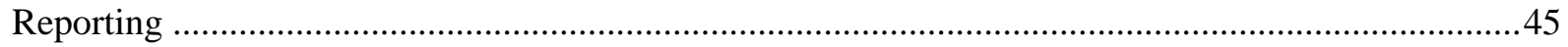

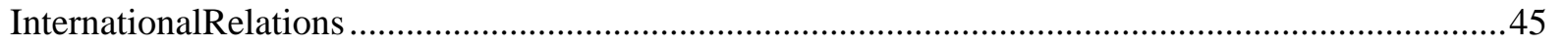

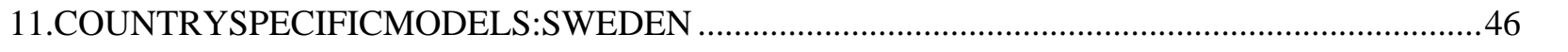

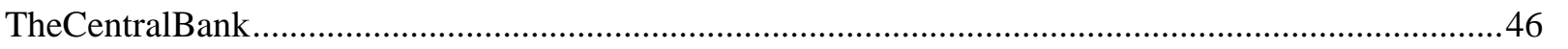

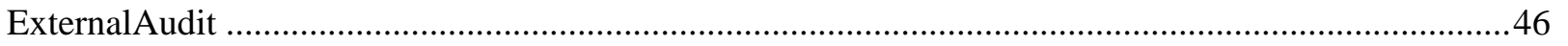

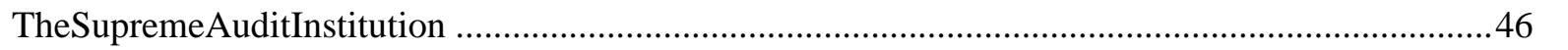

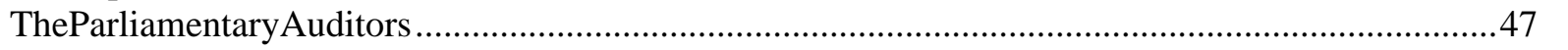

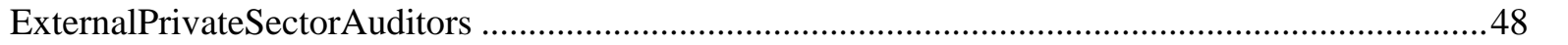

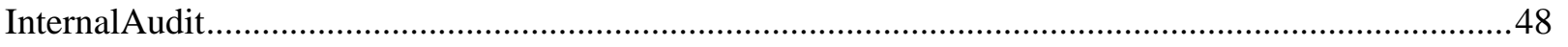

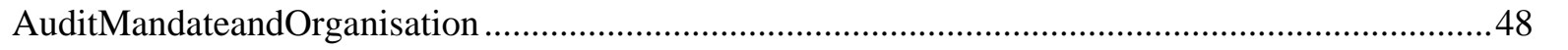

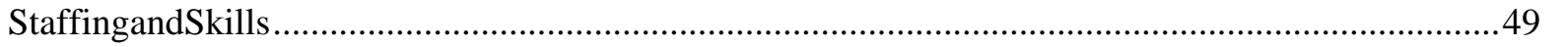

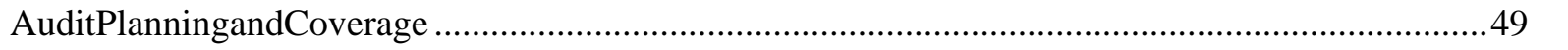

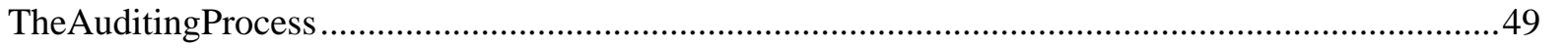

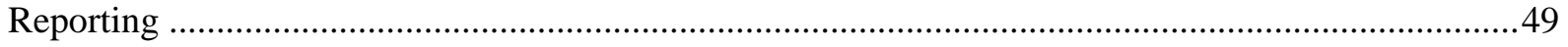

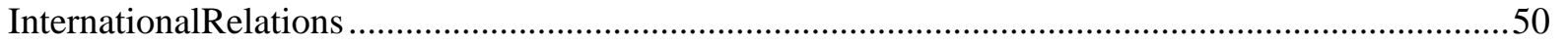

ANNEX 1. COMPARATIVE OVERVIEW OF BANK ACTS …….................................................... 51

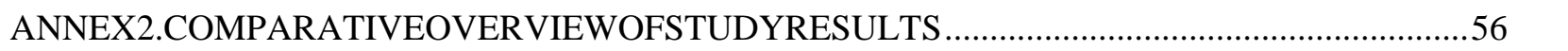

ANNEX 3. SAMPLE AUDIT PROGRAMMES: QUESTIONNAIRES FROM IRELAND......................60 


\section{EXECUTIVE SUMMARY}

In all countries, government, parliament and the central bank have concerns and responsibilities for monetary stability. Indeed, the central bank plays an important and unique role in a country's economy. This study presents the results of a selective comparison of audit practices with regard to central banks. It is not a study on banking practices. Two of the four central banks studied also perform the banking supervision function, while in two countries this function is carried out by a separate institution.

Independence of central banking from government is regarded as a fundamental principle. Each country studied here (Germany, Ireland, the Netherlands and Sweden) has developed its own unique framework for balancing independence and control.

Government and parliament play a major role in creating and maintaining an adequate control environment. In addition to the audit information received from external auditors, government and parliament receive information and signals in many other forms which contribute to their assessment of the bank's performance.

All countries have a bank act which describes the degree of independence of the central bank from government. Some bank acts describe explicitly whether or not the central bank is subject to parliamentary control. Requirements with regard to internal and/or external audit are also sometimes included in the bank act.

All countries have a supreme audit institution (SAI). But the SAI does not always have the mandate to audit the central bank. Independent external audit of the central bank is carried out by either the SAI, a parliamentary audit office or a private certified accountant. External audit in most cases includes certification of the annual accounts (financial audit) and assessment of compliance with regulatory requirements (regularity audit), as part of a discharge procedure.

Although in most cases there is no legal requirement for this, all central banks have an internal audit department, which reports to the highest level of bank management and is independent from any operational or executive functions.

The scope of internal audit is wide and ranges from financial audit and compliance audit to assessment of the results achieved (performance audit). The assessment of the reliability of internal control systems is a major area of audit, and as bank's business operations are increasingly computerised, EDP audit (electronic data processing audit) is also an important part of internal audit work.

Bank top management recognises the important role of internal audit in the framework of their managerial accountability. One of the central bank's studied has an audit committee which operates at the board of directors level and plays a role in reviewing the internal audit programme, co-ordination with the external auditor, and staffing and resourcing of internal audit. 
Independent external auditors do use to the extent possible the results of the internal audit. The review of audit programmes and audit reports, and sometimes co-ordination with internal audit plans, is an important element of the external auditor's work.

Both internal and external auditors must adhere to professional standards, including ethical codes of conduct, in performing their functions. Risk assessment, audit plans, audit programmes and reporting requirements are key elements of this.

Further developments related to the European Union and the European Central Bank point towards increased independence of central banks from national governments with a focus on macro-economic policy. This will require a re-examination of the relationship between the central bank and the parliament and government. It will also require a re-examination of the scope and solutions for independent external audit. 


\section{LIST OF ABBREVIATIONS}

$\begin{array}{ll}\text { CAATs } & \text { Computer Assisted Audit Techniques } \\ \text { CB } & \text { Central Bank } \\ \text { CEECs } & \text { Central and Eastern European Countries } \\ \text { COSO } & \text { Committee of Sponsoring Organisations } \\ \text { ECB } & \text { European Central Bank } \\ \text { EDP } & \text { Electronic Data Processing } \\ \text { EMI } & \text { European Monetary Institute } \\ \text { EMS } & \text { European Monetary System } \\ \text { ERM } & \text { Exchange Rate Mechanism } \\ \text { ESCB } & \text { European System of Central Banks } \\ \text { IAD } & \text { Internal Audit Department } \\ \text { IAPC } & \text { International Auditing Practices Committee } \\ \text { IASB } & \text { Internal Auditing Standards Board } \\ \text { IFAC } & \text { International Federation of Accountants } \\ \text { IIA } & \text { Institute of Internal Auditors } \\ \text { INTOSAI } & \text { International Organisation of Supreme Audit Institutions } \\ \text { ISA } & \text { International Standards on Auditing } \\ \text { MoF } & \text { Ministry of Finance } \\ \text { NGO } & \text { Non-Governmental Organisation } \\ \text { SIAS } & \text { Statements on Internal Auditing Standards }\end{array}$




\section{INTRODUCTION}

This report describes the central bank audit practices of four European Union Member States (Germany, Ireland, the Netherlands and Sweden).

In the first half of the report, the main features of central banks in the countries studied are introduced followed by a description of the main players involved in central bank oversight.

Next, the reader is introduced to some main concepts of control and audit, and given an overview of the organisations that play a role in the development of audit and control standards. The study continues with audit practices implemented in the four countries studied, divided into sections on external audit and internal audit.

The specific situation of each country studied is presented in separate country chapters.

In Annex 1 we provide a comparative overview of the bank acts in the four countries (limited to those aspects which are relevant to the subject of this study). Annex 2 is an overview of the study results.

In Annex 3, the reader will find a few examples of audit questionnaires which were contributed by the Comptroller and Auditor General of Ireland in response to a request by the Reference Group when this studied was under preparation. 


\section{SOME CHARACTERISTICS OF THE CENTRAL BANKS STUDIED}

\section{Functions}

1. Central banks are charged with the responsibility of keeping the physical reserves of the country (e.g. gold) and regulating the amount of money in circulation and the credit supplied to the economy. They are the sole suppliers of banknotes (the issue of coins is not always the sole right of the central bank). Central banks are responsible for monetary policy which keeps the national currency as stable as possible. They represent the national interest in relations with the International Monetary Fund, the World Bank and other international financial institutions.

2. Two of the four central banks in this study have banking supervision responsibilities. Although this study is not on banking or bank supervision practices, it is relevant to note that the principles which are relevant for bank supervision are to a great degree similar to the internal control principles of central banks. In this context, we draw the reader's attention to a recent publication by the Basle Committee on Banking Supervision ${ }^{1}$, which issued a draft framework for the evaluation of internal control systems.

\section{Shared Responsibilities}

3. Central banks play an important and unique role in a country's economy in providing for monetary stability. They share this responsibility with government and parliament. In many countries, central banks combine this responsibility with that of the bank supervision agency; in other countries, this role is assigned to a separate authority.

4. This study will not examine bank supervisory functions. It will suffice to indicate that the combined responsibility of monetary policy with bank supervision is sometimes criticised by being said to possibly create a conflict of interest. The central bank might view its primary function as protecting banks, not protecting the public interest (for example, a central bank could be said to be reluctant to raise interest rates and stem inflation whenever such actions would hurt the banks). Voters, politicians and oversight committees might view bank failures as evidence of poor supervision. Central banks, conscious of their reputation, might then refrain from monetary policy which would be disadvantageous for the banking industry, and overall monetary policy might suffer. On the other hand, separation of monetary policy from the supervision function might lead central banks to neglect the impact of monetary policy on the health of the banking system, which itself could have an impact on the nation's banking system and therefore the entire economy.

1. See Chapter 4 Audit Practices: Some Key Elements for information on the Basle Committee on Banking Supervision. 
5. The four countries that contributed to this study represent different "models":

\begin{tabular}{|l|l|l|}
\hline Country & Monetary Policy Agency & Bank Supervision Agency \\
\hline Germany & Deutsche Bundesbank & Federal Banking Supervisory Office \\
Ireland & Central Bank of Ireland & Central Bank of Ireland \\
Netherlands & De Nederlandsche Bank & De Nederlandsche Bank \\
Sweden & Sveriges Riksbank & Swedish Financial Supervisory Authority \\
\hline
\end{tabular}

6. Without entering into a discussion on the direction of reform of central banking systems, it is understood that the Maastricht Treaty is one of the points of departure for discussion on the need for reform and will provide input to decision-makers in central and eastern European countries in reshaping or reforming central banks (see Chapter 7 Some Future Developments).

\section{Independence and Control}

7. Institutions that are known as central banks emerged or were established as commercial banks or government banks. Their evolution into central banks came with their monopoly over note issue and their role as lender of last resort, among other functions. There was a conflict of interest as long as they carried out commercial business on a large scale, a practice which was thus abandoned. Dependence on government (e.g. budgetary approach; mandatory consultation; appointment and dismissal of senior management) was also seen as an obstacle to achieve best performance. But the optimal degree of dependence is a difficult matter, and furthermore changes dramatically in times of crisis. In general, independence helps to establish reputation. Reputation is key in banking and for the functioning of financial markets. It can only be acquired over time.

\section{Legal Framework — Bank Acts}

8. In all four countries studied, bank acts are in place that stipulate the responsibilities of the central bank. The acts also contain regulations on the bank management and its appointment and dismissal. In Germany, Ireland and Sweden, the bank act contains specific articles regarding the audit of the central bank. In Annex 1, we provide a comparative summary of the main elements of the bank acts, insofar as relevant to this study.

9. The reason for legal requirements is due in part to the fundamental importance attached to the impact of the success or failure of a central bank in fulfilling its intended role and the bank's place within the overall banking system. The legal requirements and the economic impact of central bank decision-making point to the need to maintain the bank's business reputation within an overall climate of stability and confidence. Therefore, it is incumbent upon management to establish an adequate governance framework to monitor, account and report back reliable information to be used for accountability purposes. In all four countries studied, integral elements of that governance framework include the existence of both an external and internal audit capacity. 


\section{Common Features}

10. The balance between parliamentary and government control over central banks and the independence of the central bank differs from country to country. Nevertheless, it is possible to identify a number of common features.

11. As mentioned above, all countries have a bank act which defines the role and responsibilities of the central bank. The act also regulates the appointment, dismissal and terms of office of the chief executive officer of the bank and the representation of government officials in the bank's supervisory or governing board.

12. All countries have a supreme audit institution (SAI). In some countries (for example, Sweden), there is also a parliamentary audit authority, when it comes to central bank audit. The mandates of these SAIs differ, but all SAIs provide an oversight mechanism for government (and to some extent for parliament) on the central banks. Depending on the mandate of the SAI, this oversight can range from regulatory audit verification of the accounts to audit of all the operations of the bank, including performance investigations. In any case, in none of the four countries studied, are monetary policy decisions subject to audit.

13. Furthermore, the central banks, in their role of banking supervisor, as well as government and parliament, can rely upon external audit by independent (certified) auditors as part of the oversight framework.

\section{Some Relevant Differences}

14. The countries studied each have their own specific system of oversight in place. Many of the differences are due to a long history of national developments. The varying roles and positions of the central bank in the respective countries are the main reasons for differences in audit practices. Not only are there differences in how independence is given shape, but these very differences in independence are then reflected in the specific planning, reporting and management practices. 


\section{KEY PLAYERS IN CENTRAL BANK OVERSIGHT}

\section{Government}

15. Government, in most cases represented by the minister of finance, is the other monetary policy-maker, together with the central bank. In this respect, central banks are close to government. Several degrees of independence exist: from total independence by law, to prior consultations with each other before any major decisions on monetary policy are made.

16. Government, in many cases, also has other interests in the performance of the central bank: the bank performs administrative functions for government. For example, the Irish Central Bank maintains the Exchequer bank account and acts as Registrar, and maintains the register of stocks issued on the domestic market by the Government, Housing Finance Agency and the European Investment Bank. In some cases, government is directly or indirectly the owner of the bank and therefore has legitimate owner's interest in the bank's performance.

17. Central banks, through the distribution of their profits, contribute to the State's treasury.

\section{Parliament}

18. The parliament's authority over the central bank varies in the four countries studied here. Parliament may have, for example, authority to elect central bank board members. Rules for the election of the board of directors, the management of the bank and its operations are laid down in the central bank act and elsewhere in law. In the case of Sweden, there is a provision for "Parliamentary Auditors".

19. Where the central bank is under the authority of parliament, the governing board of directors is de facto discharged from responsibility for its administration of the bank by a decision of parliament. As we will see, the opinion of the external auditor is a most important element in such cases.

\section{Supreme Audit Institution}

20. The main function of a supreme audit institution is to assess and give an opinion on the administration of government activities. In Germany, the Bundesrechnungshof is an independent federal body reporting directly to Parliament and Government. In Ireland, the Comptroller and Auditor General is independent and reports to Parliament. In the Netherlands, the Supreme Audit Institution is an independent high body of State and reports to Government and Parliament. In Sweden, the National Audit Office reports to Government and the Parliamentary Auditors report to Parliament.

21. The supreme audit institutions in the four countries studied all have a different mandate concerning the audit of the central bank. The Netherlands's SAI is not mandated to audit the Central Bank; external audit is performed by a private audit company, with the focus on financial audit. External 
audit of the Swedish Central Bank is carried out by the Parliamentary Auditors, who focus on regularity and performance. The Swedish SAI is not mandated to audit the Central Bank. The Irish and German SAIs clearly have the audit of their Central Banks in their mandates. The Comptroller and Auditor General of Ireland holds a certifying position in regard to all financial statements of the Bank. The German Bundesrechnungshof audits the Central Bank of Germany in respect of regularity and proper management of State property.

\section{Private Sector Auditors}

22. In almost all countries, private sector auditors are hired by supreme audit institutions or parliamentary auditors, with a view to providing an opinion on the annual accounts and (implicit or explicit) an assessment of the quality of the internal control, including the internal audit, of the central bank. The work of private sector auditors is, to the extent possible, relied on by supreme audit institutions or parliamentary auditors in carrying out effectively and efficiently their audit mandate.

\section{Internal Auditors in Central Bank}

23. Internal auditors, although employed by the central bank, are independent from operational and executive activities of the bank. The results of their internal audit work is relied upon, to the extent possible, by external auditors. They report to senior management and the scope of their work usually includes all types of audit. 


\section{AUDIT PRACTICES: SOME KEY ELEMENTS}

24. Some terminology which appears frequently in this study is introduced here, as the "jargon" of audit and control varies between countries and languages.

\section{Definitions}

\section{Management Structure}

25. There are significant differences in legislative frameworks across countries regarding the structures defined to manage and/or oversee the functioning of the central bank. Annex 1 provides a comparative summary of bank acts and identifies the main differences. For the purposes of this paper, we will distinguish between senior management as the top executive function and the supervisory board which oversees and supervises the executive body and usually has no executive powers of its own.

\section{Control Environment}

26. This refers to the attitudes and actions of the supervisory board and senior management regarding the importance of control within the bank. The control environment provides the discipline and structure for achieving the objectives of the system of internal controls. Some elements of the control environment are:

- integrity and ethical values;

- management philosophy and operating style;

- organisational structure;

- assignment of authority and responsibility;

- human resource policies and practices (see Institute of Internal Audit Standards hereafter).

\section{Internal Control}

27. Internal control can be regarded as the system of processes that include all the controls, financial or otherwise, effected by the supervisory board, senior management and other personnel to provide reasonable assurance that the following requirements are met:

- accomplishment of established goals and objectives;

- economical and efficient use of resources;

- adequate control of the various risks incurred and the safeguarding of assets;

- reliability and integrity of financial and management information; 
- compliance with laws and regulations, as well as policies, plans, internal rules and procedures (see European Monetary Institute (EMI) report on internal control systems of credit institutions).

28. Internal control and review units or groups may form an integral part of the control systems in a bank, e.g. risk control department; controlling, accounting and organisation department; or internal control sections. The mandates of such units vary but generally consist of a wide range of compliance monitoring and reporting, performance measurement, problem solving and organisational studies of working methods and procedures.

\section{Internal Audit}

29. Internal audit is a special part of the internal control system. An internal audit is an independent assessment that provides objective information on the management and cost-effectiveness of business activities and operations, systems and built-in controls, economical and efficient use and protection of resources, integrity of information and reporting, and compliance with legal statutes and organisational policies and procedures (see Institute of Internal Auditor Standards hereafter). Internal audit is performed by a unit which is part of the central bank, but the internal audit unit is not involved in any executive or operational activities and follows professional standards. The internal auditor reports directly to senior management.

\section{External Audit}

30. External audit is usually a statutory or legal requirement. Like internal audit, external audit is an independent assessment and usually ex post. However, unlike internal audit, external audit is carried out by an organisation or person that does not belong to the central bank being audited, following certain principles and standards laid down in law or by the profession. As the external audit body is not part of the central bank, there is no authority relationship between the external auditor and senior management of the central bank. In the four countries studied, no external audit institution (i.e. SAIs) has the authority to enforce its recommendations. In some countries which use a court system, there are certain ways of enforcing recommendations.

\section{Types of Audit}

31. Financial audits cover the examination and reporting on financial statements and the examination of the accounting systems upon which those statements are based.

32. Compliance or regularity audits examine legal and administrative compliance, the probity and propriety of administration, financial systems, and systems of management control.

33. Performance audit or value-for-money audit assesses the management and operational performance (economy, efficiency, and effectiveness) of public programmes and organisations in using financial and other resources in meeting their objectives. 


\section{Certification}

34. The (independent) audit of annual accounts results in an opinion of the auditors on the true, fair view of this financial information. In this respect, the audit opinion is often called the certification of the accounts. The auditors' certificate most common for financial audit is vitally important for senior management to be discharged of their liabilities by the supervisory board or parliament.

\section{Audit and Accounting Standards}

35. The audit profession has a long history. To a large degree the profession is self-regulated and has taken the initiative to develop professional standards. National initiatives on the part of organisations of audit professionals are at the origin of the standards. International co-operation in organisations, such as the IFAC and its IAPC, the IIA and its IASB, the IASC and INTOSAI (for details, see paragraph immediately below), resulted in international standards in the fields of accounting, auditing and professional conduct. Their work is growing in recognition and the standards are often accepted as "best practice", that is the standards to follow, in all sectors of society.

36. Below follows a short description of the main international organisations which are active in the field of audit and accounting standards:

IFAC - The International Federation of Accountants is the world-wide organisation for the accountancy profession. The mission of IFAC is the development and enhancement of the profession to enable it to provide services of consistently high quality in the public interest.

IAPC - International Auditing Practices Committee, a committee of the IFAC was established in 1977 and published the first International Auditing Guidelines (IAG). Those later became the International Standards on Auditing (ISA).

IASC - The International Accounting Standards Committee was formed in 1973 for the purpose of bringing into closer conformity financial accounting and reporting standards on a global basis. Over the years, the IASC has issued more than 30 standards.

IIA - The Institute of Internal Auditors was founded in 1941 by a small group of internal auditors who wanted a professional organisation that would represent their profession and provide educational activities and standards for the professional practice of internal auditing. More than 50 years later, the Institute is an international organisation that meets the needs of a world-wide body of internal auditors. Internationally, the Institute is a member and participates in the United Nations as a Non-Governmental Organisation, the International Consortium on Government Financial Management, the International Organisation of Supreme Audit Institutions (INTOSAI), and the International Federation of Accountants (IFAC).

IASB - Internal Auditing Standards Board is the technical committee of IIA responsible for promulgating and monitoring the Standards for the Professional Practice of Internal Auditing (Standards) and other Standards Pronouncements on a world-wide basis. Statements on Internal Auditing Standards (SIAS) are issued by the Internal Auditing Standards Board of the Institute of Internal Auditors.

INTOSAI - International Organisation of Supreme Audit Institutions was created to promote the exchange of ideas and experiences between supreme audit institutions around the world. 
Over 170 audit organisations and countries are currently members. INTOSAI has also regional organisations, e.g. EUROSAI, which covers Europe.

37. Supreme audit institutions (audit offices or audit courts) are the highest auditing bodies in the public sector, usually to be found at the parliamentary level. INTOSAI develops and publishes guidelines covering aspects of audit practices in the public sector. The work is done in a range of committees with participation from several countries.

38. The Accounting and Audit Committee is a permanent committee of INTOSAI which has issued Guidelines for Internal Control Standards and Accounting Statements.

39. The Committee on Audit of Public Debt of INTOSAI is summing up and developing audit practices when it comes to management of public debt.

40. The Basle Committee on Banking Supervision is a committee of banking supervisory authorities which was established by the central bank governors of the Group of Ten countries in 1975. It usually meets at the Bank for International Settlements in Basle, where its permanent secretariat is located. 


\section{AUDIT PRACTICES: EXTERNAL AUDIT}

\section{Four Country Models}

41. The requirement for an external audit function for the central bank is typically a legal requirement, contained in statutory acts and regulations governing central bank operations and explained in more detail in specific acts on audit.

42. The practices with external audit identified in this study represent four different and unique models, with different roles for private and public sector auditors. The following table summarises this:

\begin{tabular}{|l|l|l|}
\hline & \multicolumn{2}{|c|}{ External Audit } \\
\hline Country & Public Sector Auditor & Private Sector Audit \\
\hline Germany & $\begin{array}{l}\text { Bundesrechnungshof } \\
\text { (Federal Court of Audit) }\end{array}$ & $\begin{array}{l}\text { External auditors appointed } \\
\text { by the Board of Directors }\end{array}$ \\
\hline Ireland & Comptroller and Auditor General & No \\
\hline Netherlands & No & $\begin{array}{l}\text { Appointed by the Board of } \\
\text { Directors }\end{array}$ \\
\hline Sweden & Parliamentary Auditors & $\begin{array}{l}\text { Working on behalf of } \\
\text { Parliamentary Auditors }\end{array}$ \\
\hline
\end{tabular}

\section{Types of Audit}

43. The types of external audit found in the four countries differ (see table below):

- Audits of financial statements (mostly aimed at certification of the bank's accounts);

- Compliance or regularity audits (the assessment of management's compliance with laws and regulations, etc.);

- Performance audits or value-for-money, which investigate whether the objectives of the bank's activities were achieved and whether these were obtained in an efficient manner;

- EDP audits, which aim to assess the quality of computerised information systems;

- Audits of project developments, for example of EDP projects or construction projects, to assess the adequacy of management information (e.g. planning and progress feedback) required for the proper conduct of the project with a view of the (investment) risks involved;

- Special audits and investigations (e.g. fraud). 


\begin{tabular}{|l|c|c|c|c|}
\hline Type of External Audit & Germany & Ireland & Netherlands & Sweden \\
\hline Financial & $\mathrm{x}$ & $\mathrm{x}$ & $\mathrm{x}$ & $\mathrm{x}$ \\
\hline Regularity & $\mathrm{x}$ & $\mathrm{x}$ & $\mathrm{x}$ & $\mathrm{x}$ \\
\hline Performance & $\mathrm{x}$ & $\mathrm{x}$ & & $\mathrm{x}$ \\
\hline EDP & $\mathrm{x}$ & $\mathrm{x}$ & $\mathrm{x}$ & $\mathrm{x}$ \\
\hline Projects & $\mathrm{x}$ & & & \\
\hline Special & & & & \\
\hline
\end{tabular}

\section{Reporting Relationships}

44. The communication of the results of the audit work by the external auditors is to disclose results on the management and administration to the highest level of authority. In Sweden, the Auditors also, as a part of a discharge process in Parliament, make a statement whether or not — in their view — discharge of responsibilities for the Board of Directors should be given.

45. In most countries, the external auditor from the public sector reports to parliament and, where relevant, the private sector auditor reports to government (e.g. ministry of finance) and/or the public sector external auditor (the supreme audit institution). The specific reporting relationships for each country participating in this study are described under the respective country chapters, as well summarised in the table in Annex 2. 


\section{AUDIT PRACTICES: INTERNAL AUDIT}

46. This chapter describes the internal audit practices of the central banks in the four countries studied and recapitulates the most common and relevant aspects of internal audit, which are presented in more detail under their respective country chapters.

\section{Responsibility for Internal Control}

47. The role of the board of directors or central bank council includes a wide range of policy matters and business activities, duties and functions as specified in the bank act and regulations. In terms of corporate governance, the board is to ensure that there is adequate direction and control in keeping with the relevant statutory provisions for the bank's functions. It has ultimate responsibility and accountability for the system of internal controls that contribute to sound management and administration of the central bank.

48. The role and responsibility of senior bank management in various bank acts are clear as to the liability for the proper management and administration of the central bank. These responsibilities translate into the reasonable accuracy of the accounts and the effective and efficient management of resources and safeguarding of assets and other resources under the bank's control.

49. A major duty is to co-ordinate the development and implementation of management policies, practices and controls in order to satisfy their statutory responsibility. To meet its accountability, senior management has established a broad array of management control and accountability tools to report on performance within the central bank. External and internal audits in particular are essential review functions due to their inherent independence.

50. The board is also responsible for budgetary matters and that proper accounts are available for audit. The board has the important role of producing an annual report and relevant financial statements certified by independent external auditors, either by an outside accounting firm or the supreme audit institution.

51. In terms of specific control, some central banks use sub-committees, namely, an investments committee, a remuneration and budget committee, and an audit committee to manage and administer the bank to promote compliance with the bank act. These committees constitute an important element in the governance structure of a central bank. They are generally involved in the organisational structure, lines of authority and accountability of the bank. Review of strategies, plans and performance, budgets and liaison with the external and internal auditors are other important duties.

52. The board of directors and executive management of the central bank are accountable and answerable for their actions in accordance with the role and duties contained in the statutory provisions of the central bank act and regulations. As a result, there is a fundamental need to comply with these legislative requirements. 
53. Although there are usually no statutory requirements for an internal audit function (except in the case of the Swedish Central Bank), there are obvious reasons for senior management to establish and maintain an internal audit group. Internal audit enforces the overall systems of internal control and therefore adds to the incentives of management and staff to perform in accordance with the bank objectives and policies and procedures. Also, the presence of an internal audit function enables the external auditors to limit the extent of audit testing that may be necessary to issue their audit certificate and opinion as required by law.

\section{Internal Control and Internal Audit}

54. We have defined internal control as a process to help the bank achieve its goals and objectives. Internal audit is a special part of the internal control system of the central bank.

55. Internal audit as an independent assessment provides objective information on the management and cost-effectiveness of business activities and operations, systems and built-in controls, economical and efficient use and protection of resources, integrity of information and reporting, and compliance with legal statutes and organisational policies and procedures (see Institute of Internal Auditors Standards). In the four countries studied here, it is recognised that a successful audit effort must build on:

- endorsement and acceptance of a clear mandate from the board (of directors) and senior management of the bank;

- the organisational status and authority granted the auditors should be sufficient to perform the audit mandate;

- existence of a professional and competent staff to manage and carry out audits in an independent and credible manner;

- the audit programme must be performed according to standards and be flexible and responsive to changing needs of management; and

- the audit results should be used to improve the bank's operations.

56. In terms of organisational status, the head of internal audit should report and be directly accountable to the highest level practicable in the bank and/or to the board of directors. This will assist in gaining the respect and co-operation of senior management, and permit the accomplishment of audit responsibilities in an independent and objective manner.

57. Auditors should have authority to access all information, records, documents, reports, facilities, sites and equipment that are relevant to their examinations. They are also authorised to interview employees and others to obtain information and explanations.

58. Operational independence is also important in that the auditors are not to be involved in developing or implementing policies, processes, systems or procedures which they may be called upon to examine. This does not, however, preclude the ex-ante audit of new computer systems under development or major capital construction projects.

59. Audit standards exist for both internal and external auditors in the four countries studied. Although these may vary from country to country, they can be classified under general standards, field work and reporting standards. General standards relate to competence, independence and professionalism. Field standards cover planning, internal controls and evidence, and reporting standards deal with disclosure of audit opinions, and the form and content of audit reports. 
60. In terms of utility of audit results, audit standards (and the practices in the four countries) address risk assessment and specify the requirement to produce constructive, cost-effective and practical recommendations that help managers meet operational responsibilities and protect their interests by identifying opportunities for improvement. Value-added advice on the design and operation of essential control systems and the elimination of unnecessary controls and practices are also seen as important.

\section{Types of Internal Audit}

61. Central bank internal auditors in the four countries studied have the authority to audit all areas of bank activities. The scope and coverage of audits include:

- all parts of the organisation (e.g. central office operating departments, corporate support services, branch offices);

- all types of costs and revenues;

- all types of activities (e.g. procurement systems and procedures; banknote production, issuance, distribution and destruction; payment transactions; lending operations; foreign exchange transactions; trading of securities; accounting and annual accounts; construction activities and major capital investment projects; design, development and operation of computer-based systems).

62. Several audit strategies are found and are used in various ways, sometimes based on a mix of audits carried out on a surprise basis or a pre-announced basis. Surprise audits usually tend to be performed on bank operations that are considered to be high risk and are material in terms of liquidity. This includes highly sensitive business areas, such as money processing, cash payment operations, the custody of cash or vault holdings, banknote production and destruction, foreign exchange and trading transactions.

63. The audit of systems and major construction and procurement projects during the design phase prior to their implementation or completion is another audit strategy. The pay-back to such a strategy is that it is more cost-effective and timely to correct weaknesses in the control design before rather than after implementation, when large quantities of resources have been spent and a strong commitment to a faulty design has been generated. By auditing project management (including planning), costs incurred, control system design reports, management and audit trails at the start of development, the auditors are able to recommend cost savings.

64. A further audit strategy involves the reliance on the existence and quality of work performed by major controlling departments based on the scope of organisational studies and checking at the transaction level. This could significantly reduce the amount of audit work to be carried out by the internal auditors. Using a similar concept of reliance on the quality and effectiveness of the internal audit function, the external auditors can also limit their audit coverage and level of audit testing, particularly at the systems level.

\section{Reporting Relationships}

65. Principal reporting relationships of the internal auditors in the four countries studied are with the board of directors, audit committee, senior management and major internal control departments in the central bank. Proper interface is needed to co-ordinate audit effort, and to minimise unnecessary overlap and to avoid duplication of the different control groups. 
66. External and internal auditors work closely together in order to have an overall effective audit function to avoid duplication. It should be noted that this co-operation is usually not a legal requirement but based on good professional practice. Exchange of audit plans, co-ordination of planning, and information on results are typically examples found in the four countries studied where a close relation between internal and external audit was visible.

67. Positive and mutually confident working relationships between auditor and those audited are also considered to be of utmost importance for the effective fulfilment of the audit task. The audit time will be shortened and a better exchange of ideas and managerial experience will contribute to successfully meeting the audit objectives. Positive working relationships will gain commitment from senior management of the audited unit to take corrective action on reported weaknesses.

68. Based on satisfactory working relationships, summary reporting back through to senior management, the board of directors or an audit committee is facilitated, more cost-effective and gives positive results.

\section{Audit Resources}

69. Recruitment of staff varies but typical sources are universities and technical colleges, the chartered accountant community, and from within the central bank itself.

70. Skills required depend on the audit mandate in terms of the scope and objectives of the audits to be performed. Generally speaking the range of skills includes experience in management and general audit, computer systems, banking, foreign exchange and trading, engineering, financial accounting and economics. This is due to the specialist activities to be audited and the use of multidisciplinary audit teams.

71. Training and professional development of internal auditors usually are a combination of classroom and on-the-job training. This is supplemented by attendance at seminars or conferences to keep abreast of modern audit techniques, etc. Most audit organisations try to provide each auditor with at least two weeks of training per year. In some organisations, there exists a young professionals-to-hire programme, and new recruits are subsequently trained.

72. The size and amount of audit resources needed in an organisation varies according to a multiplicity of variables. It is very much dependent on factors, such as nature and complexity of bank activities, organisational structure and extent of decentralisation, audit scope and type of auditing performed, extent of computerisation, quality of existing systems and controls, volume and value of transactions, revenue, expenditures and assets and working relation between external and internal auditors.

73. For indicative purposes only, as a rule of thumb, in banking there is one internal auditor for every one hundred bank employees. Small banks, on the other hand, need a higher ratio of auditors to staff. Three auditors are generally seen as a minimum in order to maintain a high quality audit.

\section{Planning of the Audit}

74. The internal audit is typically planned on a multi-year as well as an annual basis. The plans cover selected audit units after deciding on high, medium and lower risk areas. Based on risk assessment, judgement, audit experience, and available audit resources, individual audit assignments are then normally 
scheduled on a one to three year cycle. The approved audit resources will of course influence the frequency of individual audits. Taking into account risk assessments made as part of the long-term and annual planning process, audit assignments can then be scheduled.

75. To optimise the limited audit resources, some internal audit offices have found it useful to rank in order of priority all potential audit areas. The criteria used to do the risk assessment and to schedule the individual types of audits are:

76. Materiality. This aspect of risk is a function of how reliable the system of internal controls and procedures in place are considered to be. Quantitatively speaking, the amount of revenues and expenditures, the value of the assets generated, the volume and value of payment transactions are considered to be material. In addition, the auditors also try to take into account the vulnerability to loss through fraud, theft or mismanagement, and the liquidity of cash and other assets managed.

77. Reputation and image of a central bank is extremely important in qualitative terms due to their fundamental role in the economy and this aspect has always to be taken into account in planning the audit. A lack of prudence in the implementation of monetary policy, managing foreign exchange reserves, ensuring a safe and efficient inter-bank payment system and the production and issuance of banknotes for the country could result in a loss of credibility in the eyes of the public with the devastating consequences for the country.

78. The nature and complexity of the bank operation can bear considerable risk. A specific example is the risk associated with foreign exchange transactions, such as market risk, credit risk, liquidity and processing and manipulation risks. Other areas are securities trading and holdings. Banknote production, issuance and destruction are also sensitive areas.

79. Other criteria for selecting which areas should be audited include major changes in systems or organisation, staff turnover, extent of decentralised approval authorities, the degree of computerisation and any known senior management or external auditor concerns.

\section{Performing the Audit}

80. The internal audits in the four countries studied follow a similar pattern. The basis of planning an internal audit is risk assessment. This results in identifying preliminary audit scope and objectives. These objectives are usually refined into specific attainable lines of inquiry in order to decide what to emphasise and how to perform the actual audit work.

81. A detailed planning phase normally precedes each audit assignment selected for audit. This phase involves obtaining, documenting and reviewing background information related to the bank activities under audit. A preliminary survey is made to assess whether there are any areas where improvements in bank operations are needed, or where significant concerns or risks are suspected. If additional audit work is warranted, the auditors will proceed to a more detailed examination of the major issues identified and the remainder of the control system.

82. The auditors will then proceed to review the internal control systems to ensure they are working as intended. To do this, key system controls are identified in terms of economy, efficiency and compliance. Based on the evaluation of the existence and adequacy of these key controls, the auditors determine the level and type of audit testing required. The audit testing is done to ensure if the systems and procedures performs as they are specified to do. The testing may include that a sample of actual transactions are followed in detail on how they are processed. Sometimes the auditors also use sets of 
"hypothetical" transactions to do these kinds of tests. In order to clarify it, a relevant and stable "audit trail" exists. Computer audit programs or manual audit guides and/or checklists are used in the analysis of the system, and results in an identification of deficiencies or weaknesses and risks. The cause for the situation and the resultant effects are further investigated and recorded together with appropriate audit evidence to back up all conclusions reached. Audit work has to be orderly and well documented.

83. The final phase is report writing in order to draft formally the audit observations and recommendations that will end up in the final draft audit report. Before completing the audit report, the auditors will usually obtain, after an oral debriefing of the auditees, written comments or responses to the draft report. This will serve to confirm the factual accuracy of the audit findings and to put the audit issues into a proper managerial perspective.

\section{Audit Tools}

84. All bank auditors have access to audit programmes, checklists and internal control questionnaires, covering the various activities of the central bank. This is supplemented in some banks with personal computer access to mainframe information systems of the bank. Such access is useful for auditing, not the least during the planning phase of an audit, or for data collection on different subjects or/for cost analysis.

85. Specific computer tools for auditors that are used are ACL or IDEA audit software, common office automation packages, and various spreadsheets available on the market. ACL or IDEA audit software are widely used by bank auditors for data extraction, sampling and analysis purposes, especially where there are large volumes of transactions. Spreadsheets are also used for analysis. The automation packages are used for purposes of designing graphics and documenting process flows and internal controls.

\section{Follow-up on Audit Recommendations}

86. A good audit practice is to follow up on the extent of management action in implementing measures which correct weaknesses identified in audit observations and recommendations. No matter how good the audit report may be, if no action is taken, the systems of internal control will continue to be at risk. It is incumbent upon the key players in the follow-up process to report and validate the status of improvements made as a result of the audit report.

87. As a starting point the auditors usually request a confirmation letter from management describing what actions have been taken following an audit report. In most central banks, the minimum follow-up action of this is a review of the confirmation letter. The letter is reviewed to see that all serious risks are addressed, and information is provided on the action to be taken, the implementation date and the position responsible. This ensures agreement and commitment to make the necessary changes. A letter requesting confirmation of status on progress may be subsequently sent out to management of the entity audited. The scope of the next regular audit would automatically include something on the follow-up of previous observations. Some banks will regularly do periodic on-site reviews of progress, if the audit findings are serious and warrant urgent attention.

88. Banks will then report the status of actions taken on their audit reports and unresolved issues in an annual report to the board of directors and, where applicable, to the audit committee. 


\section{Quality Control}

89. In-house supervisory and quality assurance is regularly performed on the quality of each audit itself as well as on each audit report and supporting working papers. The intent is to ensure that sufficient, appropriate and valid audit tests and evidence was gathered to afford a reasonable basis for the audit conclusions. The review of the audit report is essentially of content and form. Quality control varies between audit offices and depends, among other things, on the size of the audit entity but seems always to follow generally accepted audit standards.

90. The report conclusions must be consistent with the terms of reference for the audit assignment. Also, the audit observations must be clear, state causes and effects, and result in practical and cost-effective recommendations.

\section{Evaluation of the Audit Department's Work}

91. Apart from the assessment of the internal auditors' work for purposes of reliance by the external auditors (including the SAI), the internal audit department usually produces summary reports on performance of the audit department on an annual basis. Some banks also prepare summary annual reports to the board of directors, bank management and the external auditors for specific matters relating to lending operations and the annual accounts.

92. In addition, correspondence files and working papers and audit reports are available for trend analysis of audit issues. The activity reports sent to board of directors or audit committee members provide performance information on the audit plans in light of approved budget and available resources. Specific information is also provided on the reliance that external auditors were able to place on the internal audit function and any quantifiable cost savings.

\section{Corporate Memory}

93. The value of a good management information system for audit planning and follow-up purposes, training and continuity is acknowledged by all bank auditors met. The existence of such a system is also efficient and effective in preparing audit activity reports and year-end reporting on the state of audit, and on the overall performance of internal control systems in the bank.

94. Most bank auditors use time sheets to record and subsequently analyse for future planning purposes. The audits and their results are recorded in detail in PC (personal computer) data files or in a manual filing system (reports, correspondence and working papers). 


\section{SOME FUTURE DEVELOPMENTS}

\section{Accession to the EU - Consequences for Central Banks}

95. EU law has some clear requirements on national legislation, and thereby the function of public organisations, with bearing also on the role and functioning of the national central banks. To illustrate this, Sweden, the newest Member of the Union among the four countries studied, will be used as an example. The purpose here is just to briefly illustrate the type and scope of some of the changes initiated related to EU accession. These are changes that in turn have or may have consequences for the functioning of external and internal audit and other governance measures. It should be noted that what is referred to here will be decided in the first reading in the Swedish Parliament in spring 1998. As the proposed changes in some parts affect the Constitution, a second confirming decision by Parliament, after a general election, is needed before coming into force. The proposed timetable for the changes is that they will come into force in January 1999.

96. The most far-reaching integration of economic policy in the EU applies to monetary and exchange rate policy. The objective is that monetary and exchange rate policy is to be transferred to the EU level in order to create a stable currency area with a common, stable currency in which exchange rate and interest fluctuations no longer disrupt the internal market. Other decisions on economic policy will continue to be made by individual Member States, but the forms of co-operation are re-enforced. The final preparatory step towards a monetary union in EU was taken through the Single European Act in 1986 and the Maastricht agreement later included in the Treaty. According to these provisions, the EMU is to be introduced in three stages. In the first stage concluded end 1993, the Member States were to abolish currency regulations and other restrictions. In the second stage the European Monetary Institute (EMI) has been established. In the third stage, the European System of Central Banks (ESCB) is established and the European Central Bank (ECB) takes the full responsibility for monetary policy (decision May 1998). Each Member State also has to ensure that its national legislation, at the latest at the date of the establishment of the ESCB, is compatible with the Treaty and the Statute of the ESCB. It should be noted that this legislation shall apply to the individual central bank regardless of whether the Member State participates in the currency union or not.

97. The European Council adopted a resolution in 1978 to establish the European Monetary System (EMS). The EMS is, in addition to the resolution, based on an agreement between central banks in the EU. This agreement consists of three parts: an exchange rate mechanism (ERM), an arrangement between central banks for very short-term financing of currency interventions, and rules for the creation and use of the new common currency, the ECU.

98. The EU Treaty includes specific provisions concerning national bank legislation. The national legislation has to be compatible with the requirements of EU law but that does not mean that all requirements must be reproduced in national legal rules. The direct effect of EU law and its priority over national law makes this unnecessary. However, national provisions that conflict with EU law must be amended. Article 108 of the EU Treaty provides the following: 
99. "Each Member shall ensure, at the latest at the date of the establishment of the ESCB, that its national legislation, including the statutes of its national central bank, is compatible with this treaty and the Statute of the ESCB".

100. According to Article 109e of the EU Treaty, during the second stage, each Member State shall, as appropriate, start the process leading to the independence of the central bank in accordance with Article 108.

101. The Treaty and the Statute of the ESCB include certain requirements for central bank legislation including prohibition for the central bank and the members of their decision-making bodies to seek or take instructions from Community institutions or bodies, from any governments of the Member States or from any other body.

102. Taking what has now been said into consideration, the Swedish Parliament has taken the first steps to review the institutional framework around monetary and exchange rate policy in order to further reinforce the independence of the Swedish Central Bank, the Riksbank. Two main reasons for this are mentioned: firstly, the specific credibility problem for monetary policy and its potential negative consequences; and, secondly, the Swedish membership of the EU has entailed that the conditions for monetary and exchange rate policy have changed. The changes, to be implemented into the Constitution as well as several other laws, can be summed up as follows:

- The Riksbank should be institutionally, functionally and financially independent and the members of the body that formulates monetary policy should be given personal independence. This refers to Article 107 of the EU Treaty.

103. The institutional independence means that no one should have the right to give instructions to the bank in monetary policy matters other than by the shape of the statutory objective for monetary policy. A prohibition for agencies to determine how the Swedish Central Bank should decide in matters concerning monetary policy is to be included in the Constitution. A corresponding provision that a member of the Executive Board may not seek or take instructions when carrying out monetary policy is to be included in the existing Bank Act. Functional independence means that the Bank should be given an unambiguous role for monetary policy with the objective clearly stated in law. Financially independent means that the Bank should have sufficient funds at its disposal to be able to carry out its assignments without being controlled by appropriations from the Parliament or the Government.

104. To strengthen the personal independence, proposals are made on prohibition against instructions, disqualification rules and restrictions on the power to dismiss the monetary policy decision-makers. It should be noted here that the Treaty on EU entails limits to the extent to which removal from office can be applied. In principle, it is only possible to dismiss a monetary policy decision-maker if the person no longer complies with the requirements made on the person with respect to being able to carry out his or her duties, for example, a long period of illness, or being guilty of serious crimes or gross dereliction of duty.

- The right for the Bank to issue notes has to be changed if Sweden participates in the European Monetary Union.

105. According to the Treaty of the EU, the ECB shall have the sole right to issue notes in the Community. The ECB can delegate the issue of notes to the national banks. Only notes issued by the ECB or on its behalf will be legal tender. 
106. The paragraph above does not apply to Member States which do not participate in the monetary union.

- The management structure of the Bank is to be changed.

107. The division of responsibilities between the Governing Council of the Bank and the executive level is made more clear-cut. The Governing Council is to be given a controlling function. An Executive Board is to be created which is to decide over all monetary policy matters and to lead the Bank. The Parliament appoints the Governing Council. The Council appoints the Executive Board.

\section{- The possibilities of insight and inspection are safeguarded.}

108. It has also been seen as important to safeguard the possibilities of insight and inspection when the Bank's independence is strengthened. Several actions are taken in this respect. To increase the insight in activities in the sphere of monetary policy, the Bank shall inform the Government of all important monetary policy decisions. Furthermore, the Chair and Vice Chair of the Bank's Governing Council shall have the right to attend the meetings of the Executive Board but without the right to make proposals to vote. The Bank shall also produce a report on the monetary and exchange rate policies pursued at least twice a year. The report should be made public. It is also discussed to let the minutes of the Executive Board be published some time after the meetings.

109. The Parliament will have the possibility to evaluate activities in relation to objectives set up by the Parliament for monetary policy. The Parliament is also to adopt the balance sheet and income statements.

110. According to Article 27 of the Statute of the ESCB, the national central banks shall be audited by independent external auditors approved by the ECB Council. Adding to this demand to have an external audit, the existing law on audit is amended and extends the auditors' yearly assessment of the activities of the Bank to also include a statement to whether discharge of liability shall be extended to the Executive Board. The Parliament is the institution that decides on discharge from liability for the Governing Council and the Executive Board. 


\section{COUNTRY SPECIFIC MODELS: GERMANY}

\section{The Central Bank}

111. The position of the Deutsche Bundesbank as the Central Bank of the Federal Republic of Germany dates back to 1957 when it was established under a three-tier structure namely: Central Office, Main Offices and Branch Offices.

112. The duties and functions of the Bundesbank are contained in the Bundesbank Act. In summary, the Bank "regulates the amount of money in circulation and of credit supplied to the economy, using its monetary powers to safeguard the currency, and arrangements for domestic and international payments". It is responsible for protecting the integrity of the currency by maintaining price stability and fostering the stability of the overall banking system.

113. In implementing necessary monetary policy measures, the Bank promotes price stability and manages the foreign exchange reserves of the country. It also promotes a safe and efficient payment system by providing a system for inter-bank payments. It alone has the responsibility for the issuance of banknotes in the Federal Republic of Germany. The Bank also maintains on deposit the minimum reserves required to be held by credit institutions in the country and participates in banking supervision.

114. It acts as the principal banker and maintains accounts and makes payments for the Federal Government. It also manages and holds the country's official monetary reserves, including gold holdings.

115. The Bundesbank is an independent body that is, in its monetary policy, free from political pressure and independent from instructions from the Federal Cabinet and any ongoing parliamentary control. It generally supports the economic policy of the Federal Cabinet but "without prejudice to the performance of its duties".

116. In terms of governance, as set out in the Bank Act, the Central Bank Council is composed of the President and Vice-President of the Bundesbank, the other members of the "Directorate" and the Presidents of the Land Central Banks. The Directorate represents the central executive body of the Bank, and is accountable for implementing the decisions taken by the Central Bank Council. The Directorate consists of the President, Vice-President and up to six other members nominated by the Federal Cabinet and appointed by the President of the Federal Republic of Germany. The Presidents of the Land Central Banks are nominated by the Bundesrat and appointed by the President of the Federal Republic of Germany.

117. The Deutsche Bundesbank is composed of approximately 16000 employees. Of these, about 2570 are located at Central Office located in Frankfurt am Main, about 4750 are located in nine Main Offices (or Land Central Banks) and the remaining staff of 8680 in 167 Branch Offices. The number of the Branch Offices has been considerably reduced in the past years, and a further 18 Branch Offices will be closed by the end of 1998. Total assets as at 31 December 1996 were about 366404 Million DM. Unappropriated profit for the 1996 financial year amounted to about 9427 Million DM. 


\section{External Audit}

\section{The Supreme Audit Institution}

118. The Bundesrechnungshof (Federal Court of Audit) is a supreme federal authority. The Basic Law, the Bundesrechnungshof Act and Standing Orders and the Budgetary Principles Act specify the statutory authority, role and responsibilities of the Federal Court of Audit.

119. The Federal Court of Audit is an independent body that advises and reports directly to the Federal Parliament and the Federal Government. It is headed by a President and a Vice-President who are proposed by the Federal Government and elected by the Bundestag for a non-renewable term of 12 years.

120. The Federal Court of Audit has a mandate to carry out examinations to ensure regularity and compliance to acts, rules and regulations. Financial audits also examine financial management aspects of operations. Performance audits are conducted to ensure that value for money is obtained in terms of economy, efficiency and effectiveness in the acquisition and use of resources.

121. The Court of Audit may at any time inform the legislative bodies, the Appropriations Committee (or its sub-committee the Public Accounts Committee), and the Federal Government on matters of potential significance. The Court, when budgetary estimates are prepared, participates in the budget negotiations between the Federal Ministry of Finance and the departments, and provides testimony from an audit perspective. The Court also advises, especially the Appropriations Committee, of any risk to value for money in connection with major government projects and programmes.

122. The Central Bank Act allows the Federal Court of Audit to conduct audits of the Bundesbank. Audits at the Bundesbank occur at two levels: 1) the annual financial audit of the accounts and financial statements, and 2) separate audits of the financial management.

123. The Federal Court audits the financial management of the Bundesbank every five years. Scope and coverage include all operations, transactions, structure, procedures, cost and management accounting systems and capital investment plans and expenditures. The Court does not have a mandate to audit monetary policy. The Federal Court of Audit reviews and relies on the audit work performed by the private sector external auditors and by the Internal Auditing Department of the Bundesbank (e.g. review of reports, implementation of audit plans and use of audit resources) and takes this work into account for planning audit scope, coverage and timing. In addition, the Federal Court also has free access to Central Bank Council minutes. Audit matters are selected when drawing up annual audit plans. The Federal Court is free to set audit priorities for sample audits or leave accounts unaudited. Parliament's requests are met to the extent possible.

124. The Federal Court of Audit plans cover:

- financial management, separate property funds and federal undertakings;

- public federal corporations;

- social security institutions receiving federal grants or loan guarantees;

- private law enterprises where the Government is a shareholder; and

- audits of third parties that receive Federal funding. 
125. The Court has about 650 staff members located in Frankfurt, Berlin and Bonn. Audit staff are recruited university and polytechnic graduates. Skills and experience vary and include law, business, economics, engineering and computer fields. The Court is divided into nine audit divisions and 55 audit units organised on a functional or departmental basis. A division with a staff of six auditors is assigned to the accounts and/or operations of the Bundesbank. Audit plans involve a team of about five auditors over a six month time period and requires about 15 staff months of audit work.

126. Results of individual audits including management letters are provided to the executive of the audited entity. Auditees have the right to comment on the audit reports and the Federal Court incorporates responses into its audit reports.

127. In terms of audit tools, the Court uses audit software (e.g. ACL, IDEA) and spreadsheets to perform substantive audit testing of the accounts. A variety of checklists and questionnaires is used to perform the audit work. In-house audit seminars and external courses in money and banking can also be taken.

128. With regards to reporting, the Federal Court of Audit submits an annual report to the German Parliament (the Public Accounts Committee) and to the Federal Government. Audit findings and recommendations are made in accordance with Section 97 of the Budget Code. Observations are made public at annual press conferences.

129. The SAI has provided auditing advice to national audit institutions in Eastern Europe and China.

\section{External Private Sector Auditors}

130. The financial statements of the Bundesbank are audited by two independent external private sector auditors who are responsible for auditing the Bank's business, its accounting system and certifying the financial statements and related accounts of the Bundesbank that are subsequently approved by the Central Bank Council. Besides being sent to the Bundesbank, external auditors' reports are also sent to the Federal Ministry of Finance, the Federal Ministry of Economics and the Federal Court of Audit.

131. The external auditors' reports also examine and appraise the efficiency of the internal control and auditing systems, and make statements on the cost-effectiveness of operations. They prepare and submit a value-for-money audit report to the Federal Court of Audit.

132. The external auditors are appointed by the Central Bank Council in agreement with the Federal Court of Audit. After six years the accounting firms shall be changed.

133. Internal auditing results are made available to the external auditors, and audit plans are co-ordinated for the audit of annual accounts.

\section{Internal Audit}

\section{Audit Mandate and Organisation}

134. The mandate for the Internal Audit Function is not mentioned in the Central Bank Act or statutory authority. However, its duties, responsibilities and authority is defined in 1983 decisions and guidelines of the Central Bank Council (the supreme body of the Bundesbank). In addition, the Central 
Bank's Council's Working Party on Auditing supplements the guidelines. These documents detail the scope, reporting arrangements, responsibilities, accountabilities, and organisational relationships, etc. The internal auditor provides assurance that major risks are managed and controlled effectively throughout the Bank. The mandate covers all the Bank's business activities and operations including computer systems under development activities. Advice is provided on the quality of and compliance with established controls, and on the reliability and integrity of project management and cost-effectiveness of capital expenditures.

135. In summary, internal audit function responsibilities are to:

- examine adherence to external and internal regulations, security requirements and cost-effectiveness;

- ensure that the annual accounts are audited in co-operation with the external auditors, and provide assurance as to the reliability and accuracy of the financial statements;

- assess the need and cost-effectiveness of procurement and investment activities;

- audit construction work and capital investment projects (planning to completion); and

- audit the planning, development and implementation of automation (data processing) projects.

136. The Audit Department at the Central Office has the added responsibility for the co-ordination of internal auditing throughout the Bundesbank. The Audit Department of the Central Office also manages the "joint audit commissions" responsible for the audit of the Bank's lending business and annual accounts once a year on behalf of the Central Bank Council.

137. The Internal Audit function at the Bank is independent of management and is directly accountable to the President of the Bundesbank or to the Board of the respective Main Office. The Central Office and the nine Main Offices each have their own separate internal audit function. Under this decentralised structure, the co-ordination of audit activities is the functional responsibility of the Audit Department of the Central Office.

\section{Staffing and Skills}

138. The total number of internal audit staff is 147 of which about 30 work for the Audit Department at the Central Office. The approximate auditor ratio is presently 0.9 auditors per 100 Bundesbank employees.

139. Audit staff skills include banking, business and accounting, engineering and computers. Recruitment is usually from within other areas of the Bundesbank, university or technical colleges. New recruits receive intensive on-the-job training. For example, 3-4 months basic training in EDP is provided after about a year's practical training in auditing. Professional development and training courses average about 3 weeks per year.

\section{Audit Planning and Coverage}

140. All bank systems, business activities and organisational units are identified and assessed as to risk and part of an eight-year long-term audit plan with highest risk business areas on a yearly cycle, and average risk areas generally audited every two or three years. Audits of Bundesbank branch offices and 
computer centres are audited at three year intervals. Risks are assessed based on judgement and audit experience. Materiality, security and control requirements, potential for loss, and management concerns are also considered. Annual audit plans are submitted for approval to the President.

141. The scope and coverage includes all areas of Bank operations, and audits are conducted on both line and administrative support functions. The primary focus is on areas with highest financial risk. This includes an assessment of nature and materiality, potential for error or loss, and the reputation of the Bank. EDP systems audits, and audits of EDP systems under development are performed.

142. Audit planning also relies on a computerised database of audit observations and recommendations, which is updated after each audit. Cost savings are also identified as a result of audits. Time sheet analysis is done which assists in planning appropriate staff levels.

\section{The Auditing Process}

143. Audit methodology varies according to the type of audit performed. For systems audits, the focus is on the adequacy of internal control procedures in terms of compliance with Bank rules and regulations, but also on the security and cost-effectiveness of the business operations. Audit testing is also carried out to confirm the accuracy of the accounts. For ex-ante audits, the focus is on project management (including planning), controls and audit trails at the pre-implementation stage. Auditing is carried out at the outset of development of automated systems, construction projects and large scale procurement. This is more cost-effective than waiting until the project is completed. Regular audits of specific transactions and expenditures are audited on an ongoing basis. Special audits or investigations may of course be requested at any time. Any of the above types of audit may be applied at the transaction, system or organisational unit levels of the Bank.

144. Audit methods used at the Bundesbank include judgemental and random mathematical and statistical sampling techniques. Computer programs can be used to generate samples. Work instruments include the use of checklists. The German Institute of Internal Auditing has prepared checklists for almost all the business areas of banks, insurance and trading enterprises. Spreadsheets, internal control questionnaires, ACL and in-house audit software is used for database extraction, analysis and reporting as well as for sample selection and performing substantive and compliance testing.

145. Individual audit assignments at Central Office are normally carried out by a team of two-three auditors and require two-three weeks to complete. For auditing the Branch Offices, teams of about five-ten auditors are required for about two-three weeks. The audit strategy is based on an approach of audits done in a short time period. Audits are conducted normally on a surprise basis.

\section{Reporting}

146. All audits go through a debriefing process to confirm factual accuracy and obtain management comments. When completed, the audit reports are officially sent to the unit audited through the responsible supervisors. An information copy is also sent to the Department of Controlling, Accounting and Organisation. Relevant excerpts may be sent to other Departments.

147. In addition, three summary reports are prepared: an annual report on audit activities and performance; an evaluation of the results of the lending audits at the Bundesbank's Central Office and the nine Main Offices; and results of audits of the Bank's annual accounts, and auditing done by the nine 
Main Offices. These annual reports are sent to the President and the other members of the Directorate of the Bundesbank, and to the external auditors. The Central Bank Council receives the summary reports on lending operations and the annual accounts.

148. On-site follow-up is conducted six-nine months after the audit and only in cases where there are a large number of shortcomings. Normally a written reply and agreement to take corrective action is sufficient as follow-up action.

\section{International Relations}

149. The Bank provides technical co-operation assistance, including central bank auditing to developing countries, directly and in collaboration with the IMF. The Internal Auditing Department at the Central Office is a member of the annual G10 Heads of Audit meeting that meets to discuss audit approaches and issues related to central bank auditing. It also shares audit practices with other heads of central bank audit on a bilateral basis.

150. The Internal Audit Department is also a member of a committee of senior auditors from EU central banks and from the European Monetary Institute (EMI), which is charged with the joint audit of the development and implementation of the projects necessary for the establishment of the European System of Central Banks (ESCB), such as the TARGET payment system. This so-called TARGET Audit Group (TAG) reports directly to the Council of the EMI. TAG consists of a number of audit task forces in which the German Central Bank is also represented. 


\section{COUNTRY SPECIFIC MODELS: IRELAND}

\section{The Central Bank}

151. The position of the Central Bank of Ireland as a central bank dates back to 1942 when the Oireachtas (Irish Parliament) passed the Central Bank Act and the Bank succeeded the Currency Commission of 1927. Most recent legislative authority governing the Bank includes Central Bank Act revisions which assign additional powers and functions to the Bank.

152. As the Central Bank of Ireland, the Bank is responsible for protecting the integrity of the currency by maintaining price stability, fostering the stability of the banking system and security systems, and overseeing the safety of the payments systems and settlement arrangements. The Bank has also adopted as part of its mission statement an aspiration to seek to be efficient, cost effective, outward looking and aim for the highest levels of performance and ethical standards.

153. In implementing necessary monetary policy measures, including exchange rate policy, the Bank promotes price stability and manages the foreign currency reserves of the country. It also promotes a safe and efficient payment system by providing a system for interbank payments. It alone has the responsibility for the licensing and supervision of financial institutions, and the production, distribution and supply of Ireland's banknotes and coins. Finally, the Bank also maintains the Exchequer bank account and acts as Registrar, and maintains the register of stocks issued on the domestic market by the Government, Housing Finance Agency, and the European Investment Bank.

154. The Bank is an independent body accountable to the Oireachtas (Parliament) and is administered by a Board of ten Directors (nine of which are non-executive and appointed by the Minister of Finance). Roles and duties of the Board are covered in the Central Bank Act, 1942.

155. The Governor of the Bank is appointed by the President, on the advice of the Government, and is chairman and sole executive member of the Board. One of the directors, the Secretary of the Department of Finance, is a service (i.e. ex-officio) director, whereas other directors are normally appointed for fixed terms of five years, and come from public and private sector backgrounds. Total staff at the Bank is approximately 595, with total assets as at 31 December 1996 amounting to 5446.4 million Irf. Profit for 1996 amounted to 120.2 million Irf.

\section{External Audit}

\section{The Supreme Audit Institution}

156. The Office of the Comptroller and Auditor General is an independent body that reports directly to Parliament and its Committee of Public Accounts. It is headed by a Comptroller and Auditor General 
who is appointed by the President on the nomination of the Dáil (Lower House or House of Representatives) until the prescribed retirement age of 65.

157. The mandate of the Comptroller and Auditor General is set out in the Comptroller and Auditor General Act of 1923. The Constitution of 1937 also sets out the role of the Office of the Comptroller and Auditor General. Various amendments including the most recent in 1993 further specify role, responsibilities and statutory rights of the Office.

158. The Office has two statutory functions. The first as Comptroller General of the Exchequer to ensure that no money is issued from the Central Fund except for purposes approved by Parliament. If satisfied, the Comptroller General authorises the granting of credits from the Central Bank on the Exchequer Account. The second role, as Auditor General, deals with the audit of government accounts for accuracy and regularity, and value for money (economy, efficiency and management effectiveness) examinations.

159. The Office has statutory authority to audit the Central Bank. The Office performs financial audits to confirm the accuracy and reliability of the financial statements and supporting systems. Regularity audits also ensure that expenditures are in accordance with legislative rules. In doing so, the Comptroller and Auditor General issues an audit opinion on the statements of annual accounts of the Bank as of 31 December of each financial year. In his audit report, he certifies that proper books of account and records have been kept by the Bank, and that the statement of accounts agreed with them and gives a true and fair view of the state of the bank's affairs and of the surplus income reported.

160. The Office has about 130 employees, located in Dublin. Audit staff are recruited who are pursuing studies in the accountancy/economics field and/or who have practical work experience in the accountancy profession. Auditors must attain professional accounting qualification within five years to be appointed as auditor. Exchange programs exist with the private sector.

161. Audits of the Central Bank require an audit team working approximately 205 staff days per annum. The Audit Committee of the Bank (see Internal Audit hereafter,) and its Internal Audit function perform a valuable role in evaluating Central Bank internal control issues. The Office takes cognisance of audit work performed/planned by Internal Audit in planning its own audit coverage. Financial audit work is done on an interim basis and at year-end after the statement of accounts is received from the Central Bank (within 6 months after the end of every year). The Office uses computer assisted audit techniques (so-called CAATs) and audit software (e.g. IDEA) and spreadsheets to perform substantive testing of the accounts.

162. Annual plans are prepared for the financial audit of the Accounts of the Central Bank. In preparing its audit plans, consultation with the internal auditors and the expressed views of Audit Committee members are taken into account. Audit scope and coverage, testing and timing is co-ordinated as well throughout the annual audits. Value-for-money audits have yet to be performed on the Central Bank, but legislation to carry out such audits is included in the Central Bank Act 1997.

163. In the case of value-for-money audits, a three-stage process is used by the Office. This consists of an outline study to define the terms of reference, a preliminary study to determine if a detailed audit is warranted, and a full study that involves detailed examination and testing resulting in an audit report.

164. With regards to reporting, the Comptroller and Auditor General is required by the Central Bank Act to audit, certify, and report upon every statement of accounts transmitted by the Bank and to subsequently transmit audited statements to the Minister of Finance who in turn tables them before both 
Houses of Parliament. The audit work is performed in accordance with the standards issued by the Auditing Practices Board representing the main accountancy bodies of the UK and Ireland.

165. The Central Bank, in accordance with the provisions of the Central Bank 1989 Act, also prepares and submits an Annual Report on its activities to the Minister. If necessary, the Office of the Comptroller and Auditor General may issue a management letter if serious internal control weaknesses are evident. Audit reports are issued together with management comments, and follow-up on corrective action taken is usually done during the next annual audit.

\section{Internal Audit}

\section{Mandate and Organisation}

166. The Internal Audit Department at the Bank is independent of management, is accountable to the Governor, has a functional reporting relationship to the Audit Committee of the Board of Directors and has an administrative reporting relationship with the Assistant Director General (Human Resources, Corporate Services and Information Systems).

167. In summary, the role of internal audit is to provide the Audit Committee and management throughout the Bank with an independent appraisal of the adequacy and effectiveness of the organisation's control, custody and recording systems.

168. The Internal Audit Department provides assurance that all major risks are managed and controlled effectively throughout the Bank. Advice is provided on the quality of and compliance with established controls, and on the reliability and integrity of management information.

169. The mission of the Internal Audit Department is stipulated in the Terms of Reference as revised in January 1997 and agreed to by the Board of Directors. It details the scope, reporting arrangements, and responsibilities of internal audit and of management as well as organisational relationships, and the audit standards to be used.

\section{Staffing and Skills}

170. The Department consists of a total staff of nine inclusive of the Head of Function. The approximate budget amounts to 291000 Irf. Contracting the services of outside audit firms is limited to less than one staff year equivalent. Professional development and training courses average about one week per year per person.

171. Audit staff skills include banking, accounting, legal and EDP. Vacancies are usually filled from other areas of the Central Bank, by transfer or promotion. Staff are encouraged to pursue relevant courses of study, including those leading to qualifications in internal auditing.

\section{Audit Committee}

172. An Audit Committee has been established at the Board of Director level pursuant to Central Bank of Ireland Regulations of 1994, which defines the Committee's Terms of Reference. 
173. The Committee consists of not less than three members appointed by the Board from amongst the non-service directors. The Chairperson is also appointed by the Board, and the secretary of the Bank is his nominee. The Regulation provides for at least two meetings to be held per year. In practice, the Committee meets about four times each year. All non-service directors may attend meetings. In addition, Bank officials and the Internal Auditor may attend Committee meetings at the request of the Chairperson. The Comptroller and Auditor General may also be invited in his capacity as statutory auditor to attend meetings, and may request that a meeting be convened. The Committee is authorised to obtain required information from any Bank staff or management.

174. Major duties of the Committee are to:

- review the annual valuation of investments and the Annual Statement of Accounts before submission to the Board;

- review major proposed changes related to accounting policy that may impact upon disclosure requirements of the Bank;

- review and discuss audit matters including management letters with the Comptroller and Auditor General;

- review the internal audit programme, co-ordination with the external auditors, staffing and resources of internal audit and its standing within the bank; and

- consider major findings of internal investigations and management responses.

175. The Audit Committee is an important element of the management control framework which enhances good corporate management and accountability.

\section{Audit Planning and Coverage}

176. Annual audit plans are prepared by the Department and submitted to the Audit Committee for review in consultation with the Governor and the Management Board. Audit plans have been prepared based on a risk assessment approach that results in audit assignments being prioritised. A rolling three-year plan covering about 180 internal audit units has been prepared. This takes into account existing financial control systems and management needs.

177. The scope and coverage includes all areas of Bank operations, and audits are conducted of both line and administrative support functions. The primary focus is on areas identified as having the highest financial risk based on an assessment of materiality, potential for error or loss, and the reputation of the Bank. EDP systems audits, recently including some audit of EDP systems under development, are also carried out.

\section{The Auditing Process}

178. Audit methodology is designed to take account of both inherent and control risks, and individual audits are performed on a business or auditable units basis. Internal audit processes are based on best international practice and some informal benchmarking has been done with external organisations, including other central banks, to ensure that the audit processes are adequate. Individual audit assignments are normally carried out by a team of two auditors. 
179. A detailed audit programme (checklist) is developed and used for each audit. Attached in Annex 3 are some examples of audit checklists, offered by the Internal Audit Department. These programmes are reviewed on an ongoing basis. Internal control questionnaires are sent to auditees for completion in some instances. Microsoft Word and Excel are used for audit reporting purposes. IDEA audit software is used for data extraction, analysis and reporting, as well as for sample selection and for the purpose of substantive and compliance testing. MS Office software is used for administrative purposes.

\section{Reporting}

180. Individual audit reports are prepared by the audit team involved for subsequent review by senior staff in the Internal Audit Department. All audits go through a debriefing process to confirm factual accuracy and obtain management comments. Final reports are distributed to the head of the unit audited (and to the relevant Management Board member). In addition, a semi-annual report on past and future audit activities and on audit issues arising is prepared and sent to the Audit Committee with an advance copy to the Governor. This report forms the basis for a subsequent meeting of the Committee which in turn reports to the full Board as appropriate.

181. In discharging their responsibilities, the Internal Audit Department uses auditing standards and guidelines issued by the Institute of Internal Auditors and the main Accountancy Bodies.

\section{International Relations}

182. The Head of Internal Audit is a member of the TARGET Audit Group (TAG), a committee of senior auditors from central banks of EU Members and from the European Monetary Institute (EMI). The TAG is charged with developing a framework for the ongoing audit of the TARGET payment system and reports directly to the Council of the EMI. The TAG has formed a number of working groups on some of which the Bank is represented. The Bank also keeps abreast of governance issues that may impact on it as a result of the preparations relating to EMU. 


\section{COUNTRY SPECIFIC MODELS: NETHERLANDS}

\section{The Central Bank}

183. The Nederlandsche Bank N.V. was established in 1814. It is a public limited company, whose shares are held by the Government. The Bank Act of 1948 provides it with a large measure of independence.

184. The Bank's Governing Board is made up of a President and three Executive Directors, of which one is the Director Secretary. These individuals are appointed by the Crown for a period of seven years.

185. A Supervisory Board supervises how the Bank is managed and adapts the annual balance sheet and profit and loss account. The Government is represented by a Royal Commissioner.

186. The Bank Council is made up of 17 persons: the Royal Commissioner, four Supervisory Board Members and 12 persons appointed by the Crown. The latter represent the business sector, trade unions and experts from the world of banking and financial institutions.

187. The Nederlandsche Bank has its own task in the monetary field, which is to maintain the domestic and external purchasing power of the guilder. To ensure co-ordination of the Bank's monetary and financial policies, consultations are regularly held by the two monetary authorities, the Minister of Finance and the Bank's President. Incidentally, the law stipulates how to end possible conflicts which can not be solved in harmony ${ }^{2}$. So far these consultations have always led to agreement.

\section{External Audit}

\section{The Supreme Audit Institution}

188. The Algemene Rekenkamer was established in 1814. The Constitution of 1814 provides for a series of High Councils of State, such as the Algemene Rekenkamer, which is independent of Government and Parliament. The structure, tasks and competencies of the Algemene Rekenkamer are set out in specific acts. The primary act is the Government Accounts Act. The Algemene Rekenkamer performs regularity and performance audits. The statutes allow the SAI to rely upon the work of ministerial audit departments for much of its regularity and financial audit. The SAI does not have the powers of a Court, it can not judge or sanction those responsible for public expenditure or act as a court of appeal.

2. In such instances the Minister of Finance has the right to order the Bank to adjust its policy to the monetary and financial policies pursued by the Government. The Governing Board may appeal against such an order to the Crown, which then decide whether the order should be followed. In the Netherlands constitutional situation, this means that the Government must answer to Parliament for the decision taken. 
189. Although the Algemene Rekenkamer has the powers to examine public limited companies, with regard to the Nederlandsche Bank there is an exception (by law): it only can obtain the annual accounts and reports, and this, through the intermediary of the Minster of Finance. The SAI therefore has no mandate to audit the Central Bank.

\section{Certified Public Accountant}

190. The external audit concentrates on the certification of the annual accounts and is performed by an independent certified public accountant, as prescribed by Netherlands' law for audit of annual accounts of limited companies. Procedures for internal auditing are co-ordinated with the external auditor of the Bank, to enhance efficiency and to enable the external auditor to rely, where possible, on the work done by the Internal Audit Department.

191. The auditor's opinion is included in the annual report which is approved by the Supervisory Board and made public.

\section{Internal Audit}

\section{Mandate and Organisation}

192. The Internal Audit Department of the Central Bank reports to the Governing Board of the Bank. The Governing Board approves the audit policy, which is incorporated in an audit policy statement. The policy emphasises the relevance of the administrative organisation and internal control to ensure reliable and consistent information, and to support internal audit as a tool of management.

193. The objectives of the Internal Audit Department are the audit and certification of the Bank's internal accounts and of the annual accounts of affiliated foundations, evaluation of the administrative organisation, automated information flows, automated organisation and internal control and special assignments on behalf of the Governing Board.

194. Key in the audit is the system-oriented approach to auditing. The Bank's (financial) information systems, automated or non-automated, including their organisational context and their internal controls, are basic objects of audit. EDP audit plays an important part in the work of the Internal Audit Department and a relatively large part of the resources are used for this. Pre-implementation audits of applications is part of the EDP audit. Operational (efficiency) audit is a minor part of the work of the Internal Audit Department, with the exception of EDP systems.

\section{Staffing and Skills}

195. The Internal Audit Department has a staff of 23 (about 1.5 per cent of the total Bank staff), of which 11 work in the section for financial and operational audit and eight in the section for EDP audit. About two-thirds of the staff members have a university degree or similar qualification, of which about ten staff members are chartered accountants. There are relatively few ex-bankers. All staff have basic knowledge of computer systems auditing. Annual (ongoing) education of about two weeks per staff member is part of the planning. Occasionally some audit work is contracted-out (less than one person year). 


\section{Audit Planning and Coverage}

196. The Internal Audit Department prepares an annual audit plan. This plan has the objective of auditing major systems over a period of three to five years. In general, risk analysis on a process level is part of the audit approach. For the planning and performance of audit activities, risk analysis is performed at the level of the financial statements accounts and their potential errors. The determination whether one can rely on the existing internal controls is one of the main objects in the risk assessment. Determination of audit tolerance and material significance are other leading elements. Dutch professional guidelines which formulate generally accepted audit practices are adhered to.

197. Annual audit plans are prepared and discussed with line management. Implementation of the plan is the responsibility of the Internal Audit Department. Procedures for Internal Auditing are co-ordinated with the External Auditor of the Bank to enhance efficiency and to enable the External Auditor to rely, where possible, on the work done by the Internal Audit Department. There is no audit committee in the Bank, because it is felt that current procedures are sufficient.

\section{Internal Control}

198. The Bank's most "sensitive" Departments have Internal Control Sections which work closely together with the Internal Audit Department. The Internal Audit Department relies to a great extent on the findings of these Internal Control Sections. To give guidance to the Internal Control Sections, a manual has been compiled which provides insight into the basics underlying the implementation of internal control in the Bank. In order to ensure an effective and efficient control approach, consultations take place between the Internal Control Sections and the Internal Audit Department regarding the control activities to be performed and the outcome of examinations. Planning must be made by the manager of the Internal Control Section, in consultation with the Internal Auditing Department. This planning must be approved by the manager of the relevant department. Planning by the Internal Audit Department is based partly on planning by the Internal Control Sections.

\section{Reporting}

199. The Internal Audit Department reports formally to the Governing Board of the Bank, in practice to the Director Secretary. All reviews and investigations (about 80 per year) result in a report, with a large number of reports related to EDP audit. Copies of the reports are made available to the relevant Deputy Director and Department Manager. As a general rule, the contents of the reports is discussed beforehand with parties concerned.

\section{International Relations}

200. The Internal Audit Department has regular contacts with other Central Bank Heads of Internal Audit and participates in a Working Group on Internal Control. The Working Group has developed a list of basic principles relating to all relevant aspects regarded as appropriate to promote the establishment and the maintenance of effective and efficient internal control systems, while at the same time paying due regard to differences existing in countries in terms of legal and regulatory frameworks and the need to avoid an excessive burden on the Banks' organisations. 


\section{COUNTRY SPECIFIC MODELS: SWEDEN}

\section{The Central Bank}

201. The position of the Riksbank as the Central Bank dates back to 1668. The most recent legislative authority governing the bank is the Sveriges Riksbank Act, amended annually. In addition, the Constitution Act and the Riksdag Act make reference to its role and responsibilities and the Governing Board.

202. As the Central Bank of Sweden, the Riksbank is responsible for following developments on the foreign exchange and credit markets, and for implementing necessary monetary policy measures. The Bank promotes price stability and manages the foreign exchange reserves of the country. It also promotes a safe and efficient payment system by providing a system for interbank payments. It alone has the responsibility for the design, sorting, distribution and supply of Sweden's banknotes and coins.

203. The Riksbank is an authority under the Riksdag and is administered by eight members of the Governing Board (seven of which are elected by the Riksdag). The eighth member of the Governing Board is the Governor of the Riksbank who is elected by the Board and serves for a period of five years. Two Deputy Governors act as alternates to the Governor of the Riksbank on the governing Board during his tenure.

204. Total staff at the Riksbank is approximately 800 with total 1996 assets amounting to 212594 Million SKr.

205. Changes in corporate governance structure and practices are under consideration as a result of a recent parliamentary study of the Riksbank (see Chapter 7 herein).

206. The Bank has an international secretariat which promotes contacts with the IMF, and the European Monetary Institute (EMI), in order to have an effective organisation at the Riksbank for the preparation of issues relating to EU.

\section{External Audit}

\section{The Supreme Audit Institution}

207. The Riksrevisionsverket or the Swedish National Audit Office was formed in 1961 when the National Accounts Board and the Government Audit Bureau merged.

208. The Office is the central administrative body for government accounting and is subordinate to the Government. It is headed by an Auditor General who is appointed by the Government for a six-year term which can be renewed. 
209. Its role is not regulated by law, but by special state ordinances, which represent the current framework for its work. Although the Revisionverket's audit mandate is extensive and it enjoys full access to all information it requires for its audits, it excludes the auditing of the Riksbank. The Central Bank is, however, audited by the Parliamentary Auditors or Riksdagens Revisorer (see hereafter). The Central Bank can also access all documents that are in the public domain from the Parliamentary Auditors.

\section{The Parliamentary Auditors}

210. The primary focus of the Parliamentary Auditors is on the attainment of goals and the effects of government decisions made by the Riksdag. The overall mandate allows the Parliamentary Auditors to assess the efficient and effective utilisation of resources, including the management and use of acquired assets. Performance as well as reliable accounts are important concerns to the Auditors. As a result, the Auditors promote the most economic use of government funding, and ensure that the assets of the state are used on a rational basis. Two types of audits are performed. These include financial audits that focus on the reliability of the accounting system, accounts, and reports and internal controls. Additionally, performance audits are carried out with the focus on efficiency and productivity aspects.

211. Following the Act of Auditing the Parliamentary Administration, the Riksdagens Revisorer shall for every financial year, assess the State management and administration of the Riksbank.

212. Specific audit objectives of the Parliamentary Auditors are to:

- examine the Riksbank's Board and internal management practices and controls, and administration;

- express an opinion on the discharging of the Governing Board from liability as regards Riksbank administration;

- assess the Riksbank's annual report and income statement and balance sheet; and

- report audit recommendations and conclusions to the Riksdag.

213. The Parliamentary Auditors consist of 12 auditors and 12 deputy auditors elected by Parliament for a four-year period. A separate Office of the Parliamentary Auditors (Secretariat) which carries out the day-to-day auditing has a staff of 20 who work in close co-operation with the elected auditors. External experts are also often employed in the course of the audit work. Central Government activities are examined with proposals made to the Riksdag and reports to the Government. In essence, the Parliamentary Auditors are the Riksdag's auditing agency.

214. The total budget amounts to about 16 Million SKr. The establishment of an audit committee will be considered in the near future. At present, draft proposals and audit reports are debated and discussed at various plenary sessions and internal working and drafting committees.

215. Audits are conducted by parliamentarians with the help of the Secretariat. Performance, financial, accounting and EDP audit staff skills are required to execute the audit mandate. Economists, financial experts, accountants and auditors form part of a multi-disciplinary team depending on the scope of the audit assignment.

216. Annual audit plans are prepared based on input/consultation with the general public, Parliamentary Standing Committees, individual members of the Riksdag, and the Parliamentary Auditors and their Office. 
217. Some current audit themes in audit plans vary but cover budget and resource allocation, administrative policy, procurement, the judicial system, health care, education and the environment.

218. In line with proposals received and incorporated into the annual audit plans, individual assignment plans are prepared based on the conduct of a preliminary study or survey. The preliminary study confirms the need to proceed further with a detailed examination. An audit report that presents recommendations and conclusions is then prepared and circulated for comment by auditees. A final proposal is then made to the Riksdag. These proposals are treated in the same manner as government bills for subsequent parliamentary debate and decision. An annual report to the Riksdag is also presented by the Auditors on their own activities.

219. A so-called Statement to Parliament on the assessment of Riksbank business activities and related financial statements is submitted yearly to the Riksdag by the Parliamentary Auditors. On behalf of the Riksdagens Revisorer, the statement is signed by the chairman of the Parliamentary Auditors and the Head of the Office of the Parliamentary Auditors.

\section{External Private Sector Auditors}

220. The Parliamentary Auditors rely on a detailed report on the auditing of the Riksbank annual accounts received from external private sector auditors to prepare their assessment report to the Riksdag. That work results in an audit opinion certifying the fairness and accuracy of the annual accounts of the Central Bank. It is a report that has been established jointly by the Riksbank Auditing Department and the private sector auditors.

\section{Internal Audit}

\section{Audit Mandate and Organisation}

221. The operations of the Auditing Department are stipulated in the Sveriges Riksbank Act, 1988:46, Article 35, which specifies that the Head Office of the Riksbank contains an Auditing Department within the Bank. The Auditing Department at the Riksbank is accountable to the Governing Board.

222. In addition, the Act on the Auditing of Parliamentary Administration and an internal Riksbank auditing instruction, describe the role and responsibilities of the Auditing Department. These are summarised in the Bank's annual report and are:

- to see that the accounts are true, fair and in accordance with good accounting practice;

- inspect internal controls with particular reference to safeguarding the value of the Riksbank in light of the Riksbank's holdings; and

- ensuring that the Bank maintains a fully satisfactory quality of information systems security in accounting, statistical and related information systems. The Auditing Department makes audit observations and recommendations regarding efficiency and the meeting of bank objectives. 


\section{Staffing and Skills}

223. The Auditing Department consists of a staff of nine auditors The approximate budget amounts to 4 Million SKr. Contracting the services of outside audit firms is limited to less than one staff year equivalent. Professional development and training courses average about two weeks per year. This is supplemented with on-the-job training and working with consultants and the external auditors.

224. Senior experienced auditors perform the audit work according to bank needs. Audit staff skills are primarily financial accounting and EDP auditing in nature. Recruitment is usually from outside audit firms, the National Audit Office and the commercial banks.

225. An audit committee for the Bank is currently under discussion.

\section{Audit Planning and Coverage}

226. Annual audit plans are prepared and submitted for adoption by the Governing Board. Supplementary planning documents for all audit fields map out audit work for up to three years.

227. The scope and coverage include the whole area, in particular foreign currency systems and transactions, the audit of the financial statements, 11 regional branches, eight currency depots, EDP auditing (systems under development included), and an effectiveness and management audit of some organisational functions. The primary focus is on accounting and internal control, especially in connection with valuables, information and systems security. In particular, the audit work performed on the Riksbank's annual report and accounts is used by the Parliamentary Auditors to satisfy their mandate relating to regularity.

\section{The Auditing Process}

228. One impressive aspect to auditing at the Riksbank is found in the area of risk assessment which is based upon inherent control and materiality. Combined risks are looked at during the planning stage (of EDP systems) in terms of significance (relative importance of operating field, sensitivity, transaction attributes and general ledger attachment). These are subsequently analysed in terms of risks for disclosure, alteration, destruction and access to information. Appropriate risk levels (low, medium, high) are then applied to specific Bank systems and operations to establish priorities for audit. Other risk assessment methods are as well developed for financial auditing and branch office auditing.

229. Work instruments include a combination of audit programmes and internal control questionnaires. Mainframe tools are used for extraction and analysis; ACL audit software is also used for data extraction, analysis and reporting as well as for sample selection and performing substantive tests on balance sheet accounts. MS office software is used for administrative purposes; a specific application called DB2 is used for time accounting. To assist in follow-up, audit planning and requests for information, a common storage of audit recommendations (e.g. with the use of MS Access) is maintained for the Auditing Department.

\section{Reporting}

230. Individual audit reports are distributed to some or all of the following parties, depending on circumstances: the Governing Board, the Governor and senior Bank auditees. Executive summaries 
always exist for the introductory part of each report. In addition, an annual report on the plans and achievements and activities of the Auditing Department is prepared and transmitted to the Governing Board and Senior Bank Management.

231. The Auditing Department of the Riksbank is also responsible for sending the annual report on the accounts to the Office of the Parliamentary Auditors.

232. Follow-up of implementation of audit recommendations is done semi-annually or when the next audit is scheduled.

\section{International Relations}

233. The Auditing Department is a member of the annual G 10 Central Bank Heads of Internal Audit meeting. This is a forum which allows peers to debate audit and internal control issues and to share recent developments and lessons learned in the field of central bank auditing. 

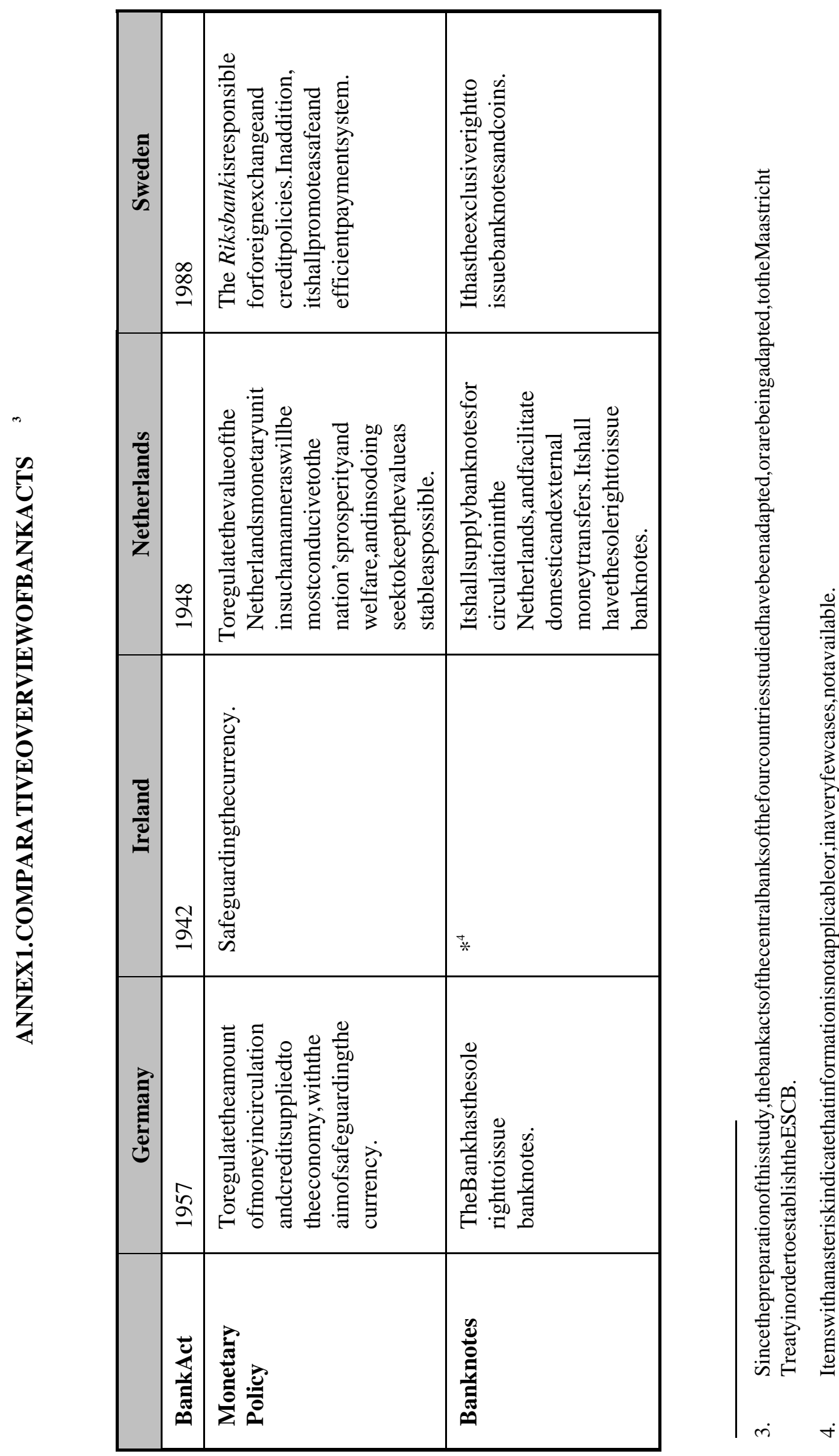


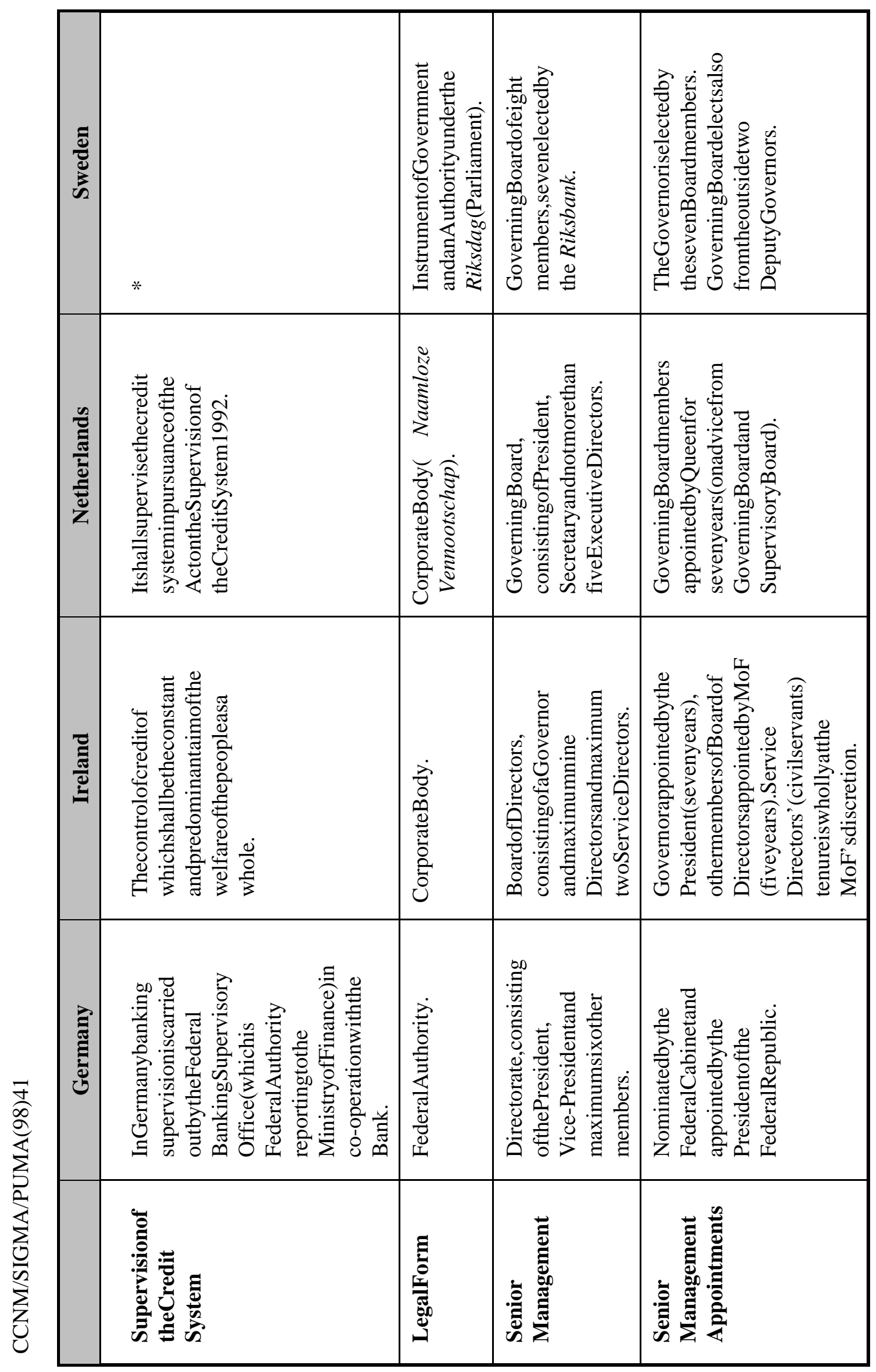




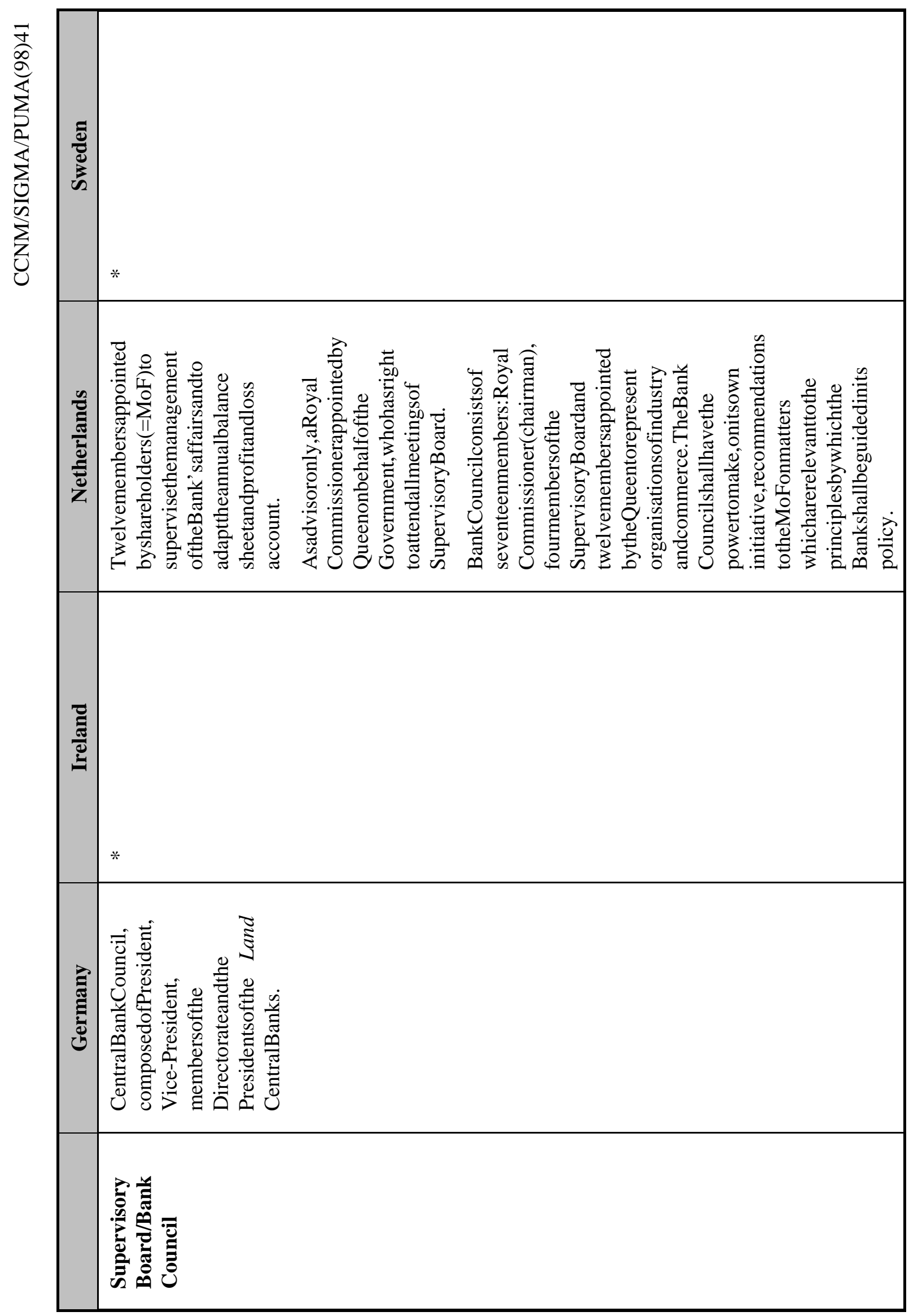




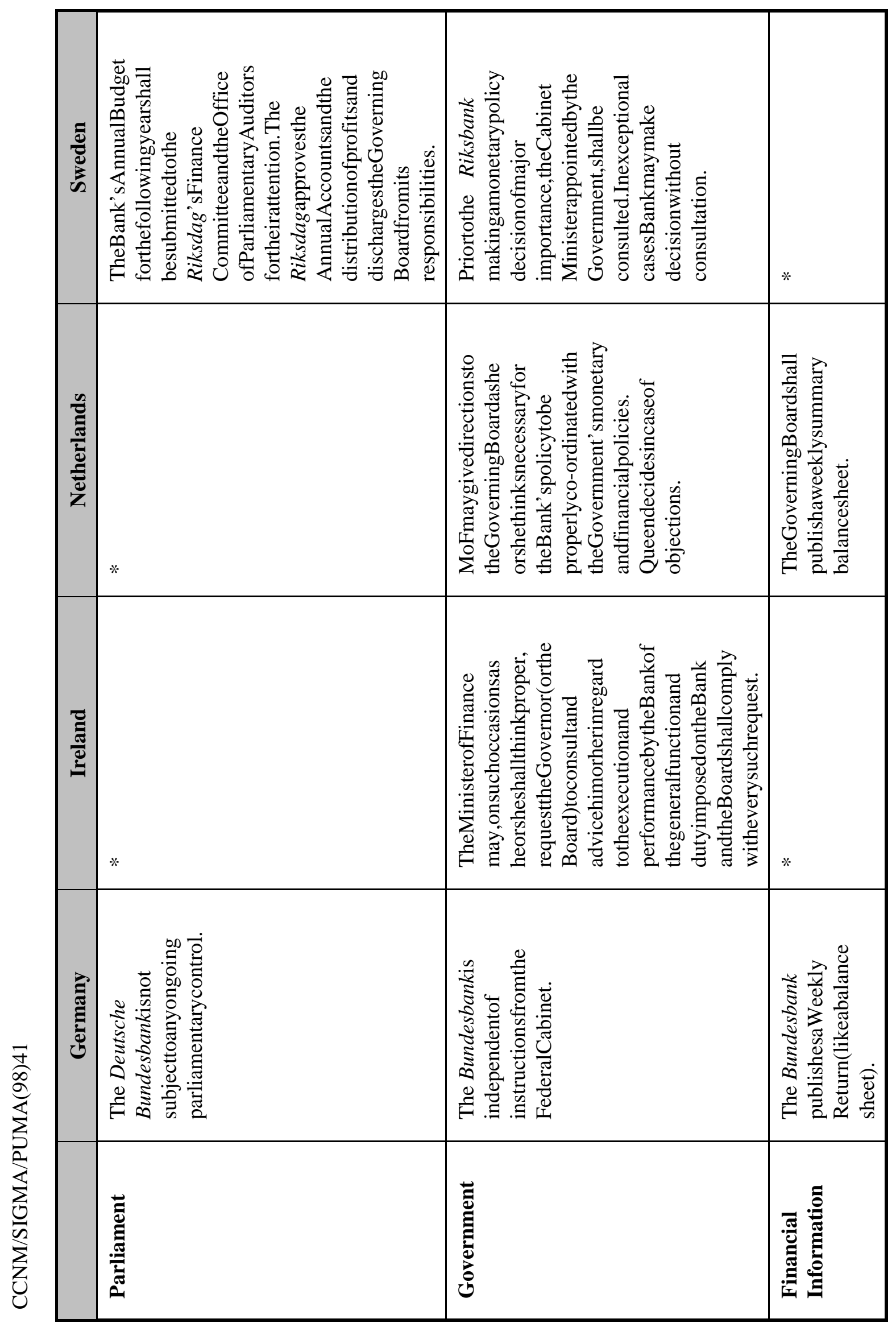




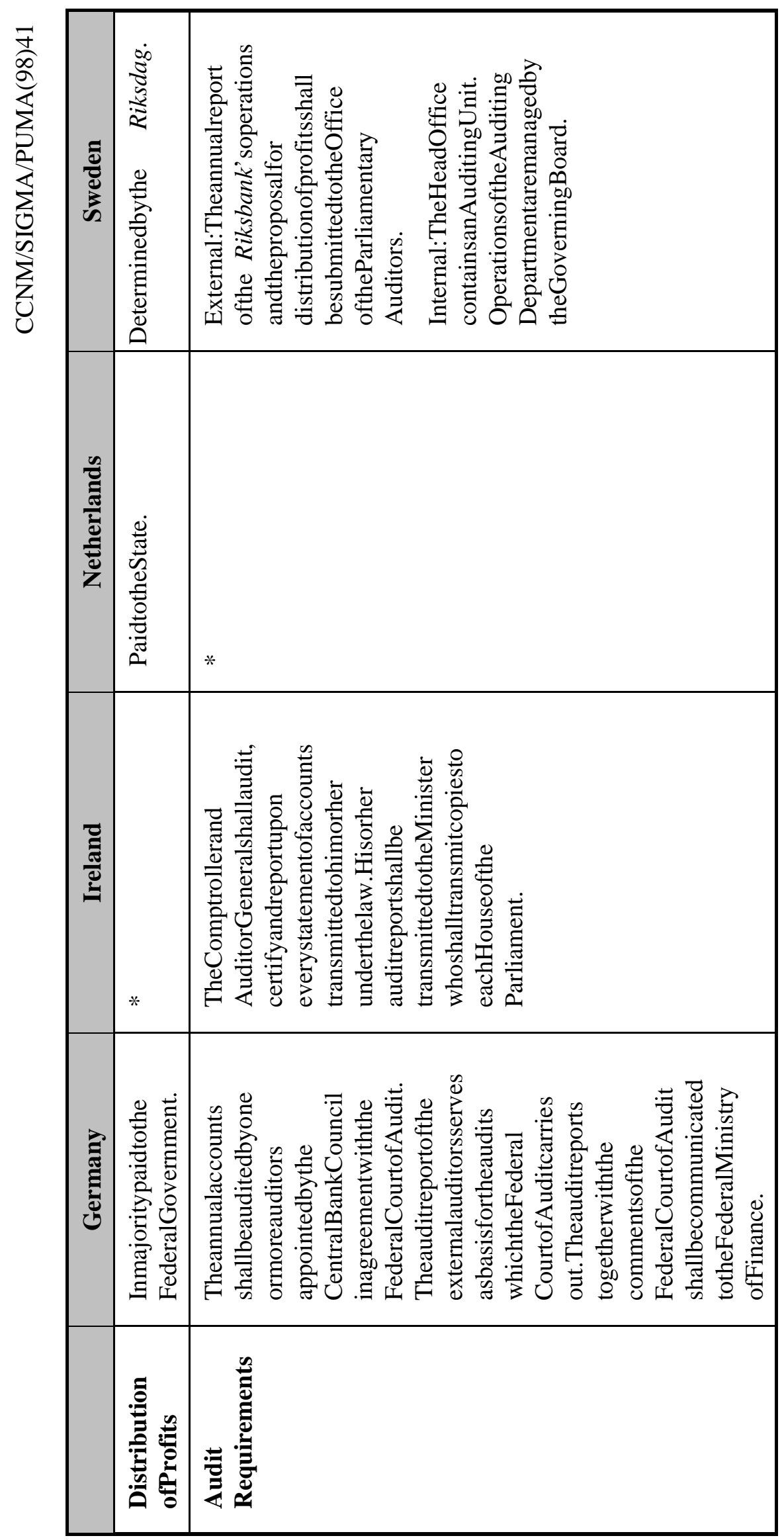




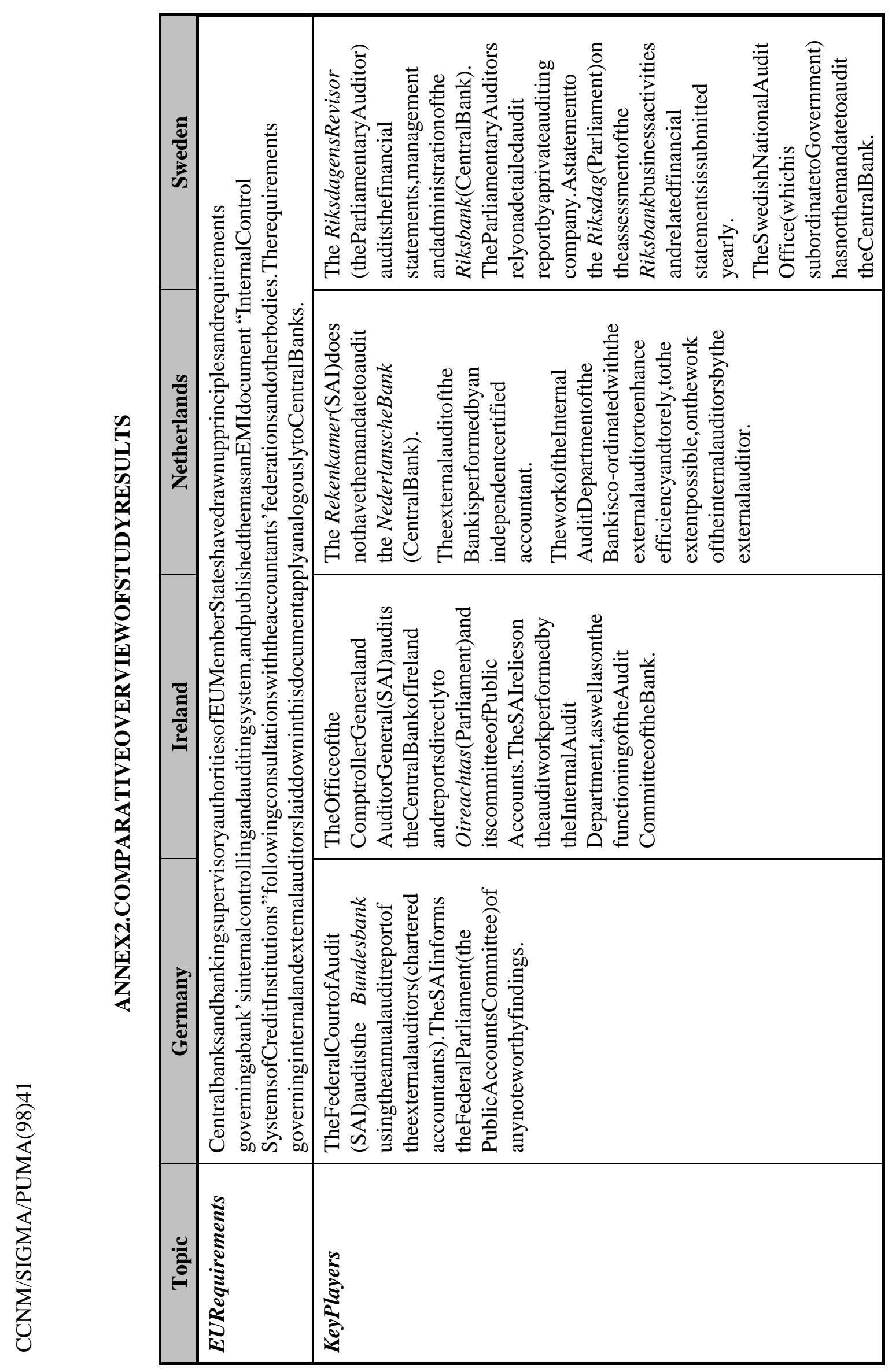




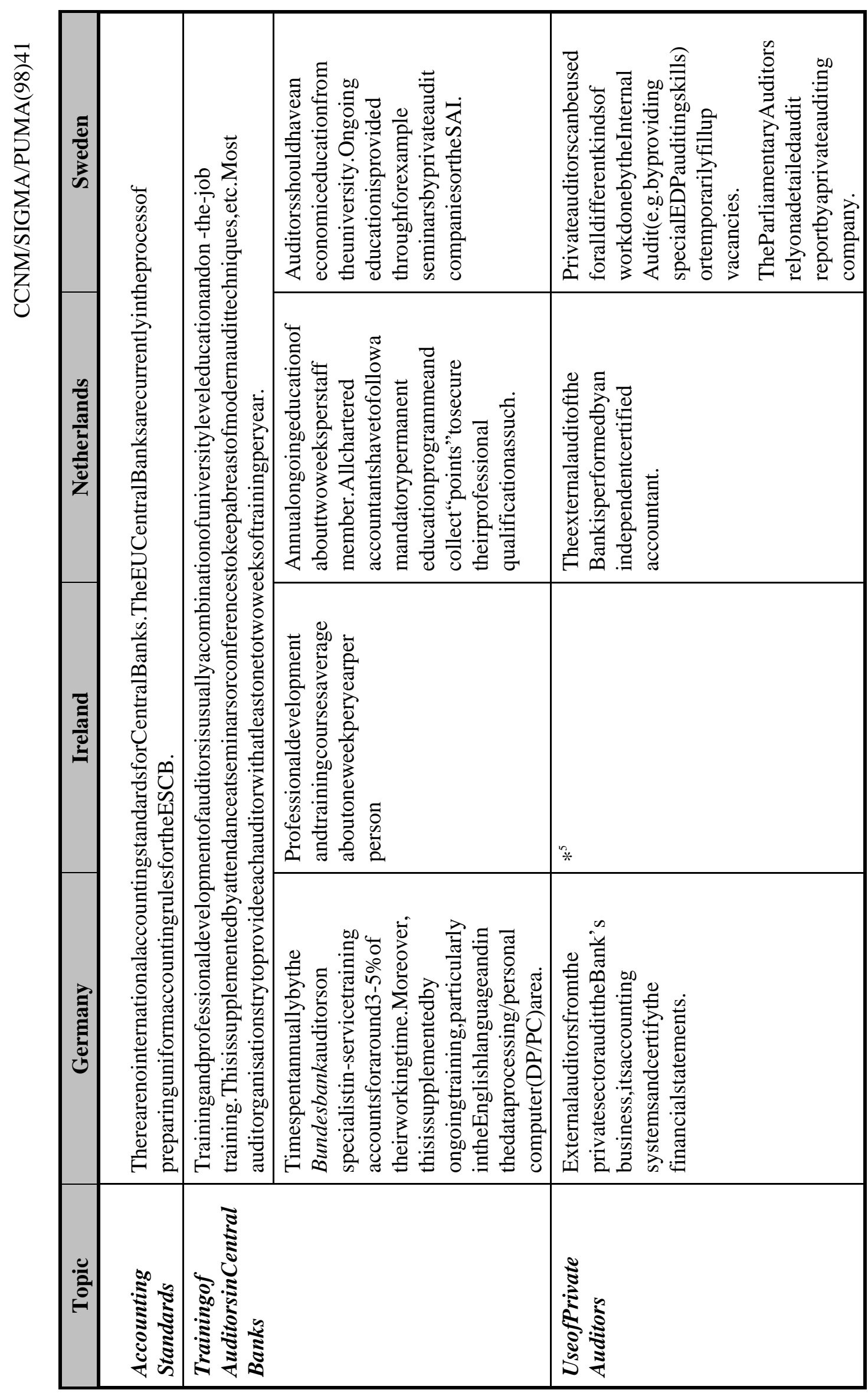

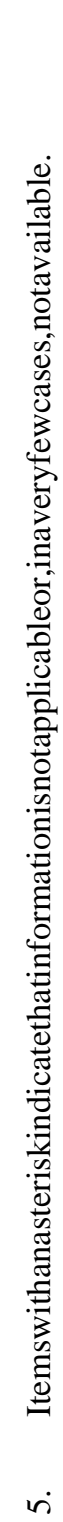




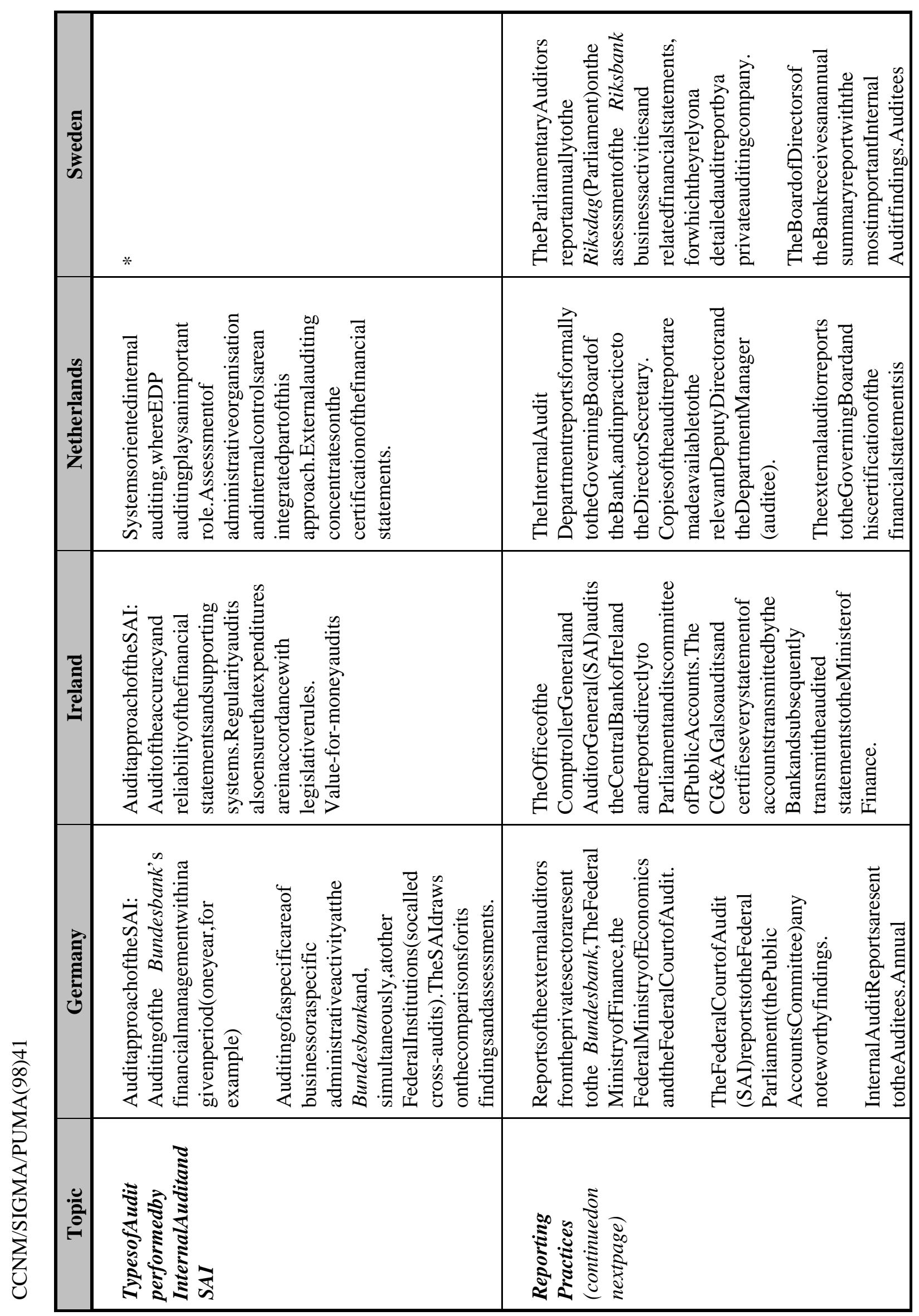




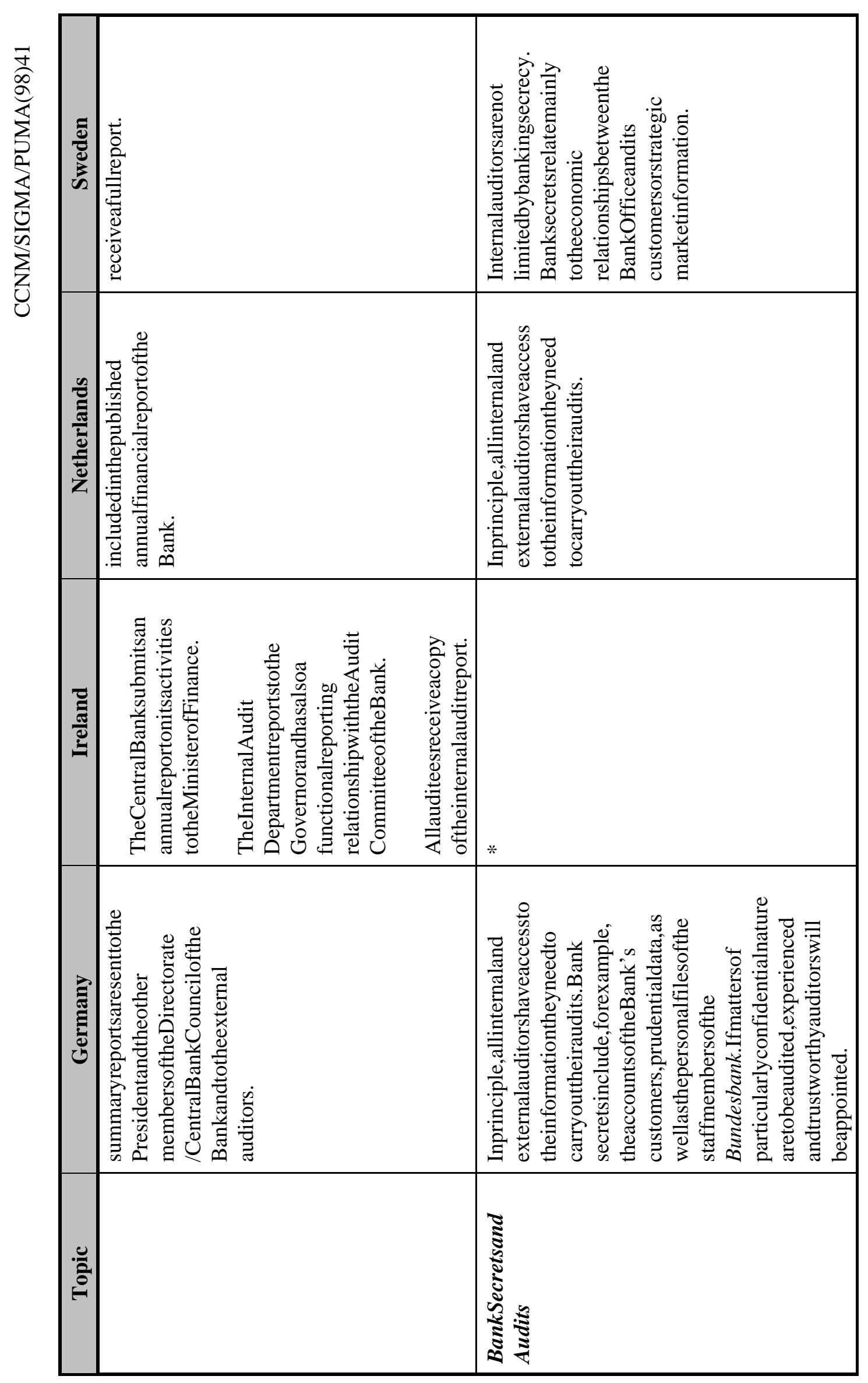

in 
ANNEX 3. SAMPLE AUDIT PROGRAMMES: QUESTIONNAIRES FROM IRELAND

AC027-01

\section{COMPTROLLER AND AUDITOR GENERAL}

Control Evaluation Form

Organisation/Vote:

Creditors

\begin{tabular}{|l|l|l|}
\cline { 2 - 3 } Prepared by & Year & 19 \\
\cline { 2 - 3 } Reviewed by & $\begin{array}{l}\text { Initials } \\
\text { /Date }\end{array}$ & \\
\cline { 2 - 3 } & $\begin{array}{l}\text { Initials } \\
\text { /Date }\end{array}$ & \\
\cline { 2 - 3 } &
\end{tabular}

Date of Previous Audit

Prior Current

Audit Audit

\section{A. KEY QUESTION}

Are controls adequate to ensure that:

1. suppliers statements reconcile with creditors ledger accounts and the creditors control account.

2. all trade creditors and accruals have been established as existing, at the stated amount and recorded.

3. no liabilities can be omitted.

4. all entries in the creditors records are authorised. 
Prior Current

Audit Audit

\section{B. INTERNAL AUDIT}

Was this area the subject of an Internal Audit Review in the year? If so, attach a copy of the report to the working papers file.

\section{SPECIFIC CONTROL CRITERIA}

1. Is there a system for reconciling creditors ledger accounts and suppliers statements?

2. Is the list of creditors balances agreed regularly with the control account and differences reconciled?

3. Are credits and allowances due from suppliers accounted for properly?

4. Are debit balances reviewed and followed up?

5. Are transfers between purchases and sales and nominal ledger accounts authorised?

6. Are year end cut off procedures adequate?

\section{DISCIPLINARY CONTROLS}

1. Have the operations, procedures and systems in this area been sufficiently documented?

2. Is there adequate separation of function?

3. Have appropriate limits of authority been set?

4. Is there adequate supervision?

5. Are checks properly evidenced?

6. Is the frequency of checks sufficient? 
Prior Current

Audit Audit

E. COMPUTER PROCESSING CONTROL CRITERIA

(Refer to Computer Processing Controls Evaluation Guidelines)

What segment of this area are performed by computer?

1. Is input controlled?

2. Is input checked?

3. Are there controls over standing data changes and completeness?

4. Are there controls over rejected input?

5. Are there controls over suspense items?

6. Is there an effective Data Control Section?

7. Are there adequate security arrangements?

8. Are there updating and balancing of transactions and masterfile controlled?

9. Is the transfer of data in integrated computer systems controlled?

10. Are there user controls over output?

11. Are Manual Issues controlled in the computerised system?

12. Is there control over Cancellations?

\section{F. PRELIMINARY RISK ANALYSIS}

The exposures of the organisation in this area are: 


\section{COMPTROLLER AND AUDITOR GENERAL}

Audit Programme

Organisation/Vote:

Creditors and Accruals

Year.....

Obj.

Intl. Comments Major

/Date /WP Ref. Points

\section{Objectives:}

A. To establish that all trade creditors and accruals are recorded in the accounting records.

B. To establish that all recorded trade creditors and accruals exist.

C. To verify that all sums so described are current liabilities of the organisation at the amount stated.

\section{Procedures:}

\section{A. Analytical Review}

Perform appropriate analyses on this area and review the relevant ratios and trends.

\section{$\mathrm{AC} \quad$ B. General}

1. Obtain a list of creditors and accruals to agree with the Balance Sheet figure.

2. Check the listing of trade creditors against the individual balances in the creditors ledger.

3. Check the tots on the listing.

4. Examine creditors ledger and:
a. check that individual creditor balances appear to be made up of specific and recent invoices; and
b. book out for unusual items;
c. check the tots on the ledger. 
Intl. Comments Major

/Date /WP Ref. Points

5. Scrutinise the reconciliation between suppliers statements and the balances on the creditors ledger.

6. Investigate all significant debit balances arising from the following headings and consider whether they should be reclassified as debtors:
a. overpayments;
b. unrecorded invoices;
c. prepayments, or;
d. misposting.

$\mathrm{AC}$

\section{Creditors Control Audit}

1. Verify that the nominal ledger creditors control account is reconciled to the balance on the creditors ledger.

2. Examine the above reconciliation checking:
a. contras;
b. adjustments or unusual items with supporting evidence;
c. subsequent clearance of adjustments.

3. Examine Creditors Control Account (in the Nominal Ledger); and
a. check additions and balances forward;
b. enquire into any apparent unusual entries;
c. compare balance on the account month by month and if there is a sharp increase in the trend enquire into the reasons.

\section{Posting}

1. Post Cheque Payments from Cheque Payments Book/Listing to the creditors accounts in the creditors ledger. 
Intl. Comments Major

/Date /WP Ref. Points

2. Check posting of creditors cheque payments totals from the Cheque Payments book/listing to Creditors Control Account in the Nominal Ledger.

3. Review creditors ledger journals and check validity of transactions with underlying documentation.

\begin{tabular}{|cc|}
\hline $\mathrm{SS}-$ & $\mathrm{SM}-$ \\
\hline
\end{tabular}

B E. Circularisation

Circularise creditors, reconcile the replies with the list of balances investigating any discrepancies, and follow up creditors for whom no replies were received.

$$
\mathrm{SS}-\quad \mathrm{SM}-
$$

F. Accruals

1. Examine schedule of accrued expenses at year end for completeness and accuracy by reference to:
a. subsequent payments;
b. agreements;
c. previous year's accruals; and
d. nominal ledgers.

2. Ensure that prepayments policy with respect to suppliers is reasonable.

\section{B G. Cut-off}

1. Test the year end cut-off procedures by examining:

Purchase orders raised;

$$
\text { SS - SM - }
$$

Goods received records;

$$
\text { SS - SM - }
$$

Goods returned records; 
Intl. Comments Major

/Date /WP Ref. Points

\begin{tabular}{|cc|}
\hline $\mathrm{SS}-$ & $\mathrm{SM}-$ \\
\hline
\end{tabular}

Purchase invoices;

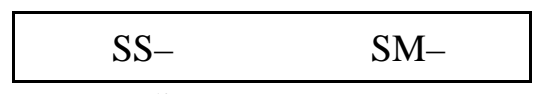

Credit Notes.

\begin{tabular}{|ll|}
\hline $\mathrm{SS}-\mathrm{SM}-$ \\
\hline
\end{tabular}

2. In relation to cut-off procedures, ensure that all goods received have been included in the Purchases/Creditors system and that associated costs and expenses have been accrued or charged in the case of all purchases.

\section{H. Foreign Currency}

1. Verify that creditors and accruals denominated in foreign currencies have been translated to IR Punts at the appropriate exchange rates for annual accounts purposes. 
AC028-01

\section{COMPTROLLER AND AUDITOR GENERAL}

Control Evaluation Form

Organisation/Vote:

Debtors

\begin{tabular}{|l|l|l|}
\cline { 2 - 3 } Prepared by & Year & 19 \\
\cline { 2 - 3 } Reviewed by & $\begin{array}{l}\text { Initials } \\
\text { /Date }\end{array}$ & \\
\cline { 2 - 3 } & $\begin{array}{l}\text { Initials } \\
\text { /Date }\end{array}$ & \\
\cline { 2 - 3 } &
\end{tabular}

Date of Previous Audit

Prior

Current

Audit

Audit

\section{A. KEY QUESTION}

Are controls adequate to ensure that:

1. the debtors control accounts agrees with the sum of the debtors ledger account balances?

2. all debtors and prepayments have been recorded at their correct value?

3. all entries in the debtors records are authorised and that no entries are omitted?

4. all debtors balances are collectible or that a proper provision for bad debts has been made?

5. all available discounts taken? 
Prior Current

Audit Audit

B. INTERNAL AUDIT

Was this area the subject of an Internal Audit Review in the year? If so, attach a copy of the report to the working papers file.

\section{SPECIFIC CONTROL CRITERIA}

1. Is there a periodic reconciliation of the debtors control account in the debtors ledger?

2. Are statements sent regularly to customers?

3. Are receipts which are not in accordance with invoiced amounts investigated?

4. Are credit balances reviewed and followed up?

5. Are aged analyses of debtors prepared, reviewed and acted upon?

6. Is there proper control over the classification and writing off of bad debts?

7. Are appropriate settlement terms in operation?

8. Are discounts taken checked for validity?

\section{DISCIPLINARY CONTROLS}

1. Have the operations, procedures and systems in this area been sufficiently documented?

2. Is there adequate separation of function?

3. Have appropriate limits of authority been set?

4. Is there adequate supervision?

5. Are checks properly evidenced?

6. Is the frequency of checks sufficient? 
Prior Current

Audit Audit

\section{E. COMPUTER PROCESSING CONTROL CRITERIA}

(Refer to Computer Processing Controls Evaluation Guidelines)

What segment of this area are performed by computer?

1. Is input controlled?

2. Is input checked?

3. Are there controls over standing data changes and completeness?

4. Are there controls over rejected input?

5. Are there controls over suspense items?

6. Is there an effective Data Control Section?

7. Are there adequate security arrangements?

8. Are there updating and balancing of transactions and masterfile controlled?

9. Is the transfer of data in integrated computer systems controlled?

10. Are there user controls over output?

11. Are Manual Issues controlled in the computerised system?

12. Is there control over Cancellations?

\section{F. PRELIMINARY RISK ANALYSIS}

The exposures of the organisation in this area are: 
AC028-01

\section{COMPTROLLER AND AUDITOR GENERAL}

Audit Programme

Debtors and Prepayments

Year.....

PLANNING: I have taken the exposures noted on the CEF into account in planning the type and level of tests. Based on these exposures, I approve the audit objectives and plan as set out in this audit programme.

Senior Auditor.

Date.

CONCLUSIONS: I have completed the programme of work set out in the audit programme below. The major points which need to be addressed are detailed on the Major Points Arising Form.

Auditor.

Date.

AUDIT REPORT: On the basis of my evaluation of the controls as confirmed by the audit testing, I rate the control risk as (High/Medium/Low).

On the basis of the programme of work set out beneath, I confirm that the audit objectives have been achieved subject to the points outlined in my report.

Senior Auditor.

Date.

SIGN-OFF OF AUDIT: I have reviewed this programme and its completion. The following action should be taken.

Deputy Director.

Date.

Obj.

Intl. Comments Major

/Date /WP Ref. Points

\section{Objectives:}

A. To establish that all debtors are recorded in the accounting records.

B. To establish that all recorded debtors are valid, exist at the year end and are stated at the correct amount.

C. To confirm that all debts are collectible and, if not, that a proper provision is made for bad and doubtful debts. 
Intl. Comments Major

/Date /WP Ref. Points

D. To ensure that all expenditure prepaid has been calculated on a reasonable basis.

\section{Procedures:}

\section{A. Analytical Review}

Perform appropriate analyses on this area and review the relevant ratios and trends.

\section{B. General}

1. Obtain a list of debtors and prepayments to agree with the Balance Sheet figure.

2. Check the listing of trade debtors against the individual balances in the debtors ledger.

3. Check the tots on the listing.

4. Examine debtors ledger and check:

a. that customers credit limits have not been exceeded.

\begin{tabular}{|c|}
\hline $\mathrm{SS}-$ \\
$\mathrm{SM}-$
\end{tabular}

b. unusual items (eg. allowances, payments on account);

c. check the tots on the ledger.

d. that significant unallocated cash balances are not present;

e. additions and balances forward;.

f. credit balances.

5. Obtain an aged analysis listing in respect of trade debtors and scrutinise for significant items.

6. Check that statements are sent to customers on a regular basis. 
Intl. Comments Major

/Date /WP Ref. Points

7. Check that all overdue accounts are followed up for collection.

\section{Debtors Control Account}

1. Verify that the debtors control account in the nominal ledger is reconciled to the balance on the debtors ledger.

2. Examine the above reconciliation checking:
a. contras;
b. adjustments or unusual items with supporting evidence;
c. subsequent clearance of adjustments.

3. Examine Debtors Control:
a. check additions and balances forward;
b. enquire into any apparent unusual entries;
c. compare balance on the account month by month and if there is a sharp increase in the trend enquire into the reasons.

\section{Posting}

1. Check the individual postings from the receipts records to the debtors ledger.

2. Check the posting totals from the receipt records to the nominal ledger control amount.

3. Review debtors ledger journals and check validity of transactions with underlying documentation.

\section{E. Circularisation}

1. Circularise a sample of debtors..
SS -
$\mathrm{SM}-$ 
Intl. Comments Major

/Date /WP Ref. Points

2. Reconcile the replies with the list of balances investigating any discrepancies.

3. Follow up debtors for whom no replies were received.

\section{F. Non Trade Debtors and Prepayments}

1. Obtain a list of debtors (other than trade debtor balances) and prepayments at year end:

\begin{tabular}{|cc|}
\hline $\mathrm{SS}-$ & $\mathrm{SM}-$ \\
\hline
\end{tabular}
a. vouch with invoices/statements or other suitable evidence;
b. tests calculations;
c. scrutinise accounting records for any items which may have been omitted from this list, eg. rents, insurance.
d. ensure that these items have been properly recorded in the nominal ledger and are correctly shown in the accounts.

2. Vouch with invoices/statements or other suitable evidence.

3. Test calculations.

4. Scrutinise accounting records for any items which may have been omitted from this list (eg. rents, allowances).

5. Ensure that these items have been properly recorded in the nominal ledger and correctly shown in the accounts. 
Intl. Comments Major

/Date /WP Ref. Points

\section{G. Bad Debts}

1. Verify that debtor balances at year end are fully realised in the next period by reference to cash book, bank statements, etc.
SS -
$\mathrm{SM}-$

Investigate any accounts not cleared and consider the impact on the bad debts figure.

2. Check bad debts written off with relevant correspondence and authorisation.

3. Ensure that any potential for subsequent recovery is followed up.

\section{H. Cut-Off}

Verify that creditors and accruals denominated in foreign currencies have been translated to IR Punts at the appropriate exchange rates for annual accounts purposes.

1. Sales orders received.

2. Goods despatch (returns) records.

3. Sales invoices.

4. Credit notes, to ensure that all goods delivered or services performed have been included in the sales/debtors system.

\section{Foreign Currencies}

1. Verify that debtors and prepayments denominated in foreign currencies have been translated to IR Punts at the appropriate exchange rates for annual accounts purposes. 